December 1998 • NREL/SR-540-25114

\title{
Cummins Engine Company B5.9 Propane Engine Development, Certification, and Demonstration Project
}

\section{February 1997 — June 1998}

\author{
The ADEPT Group, Inc. \\ Los Angeles, California
}

Alternative Fuels Hotline: 1-800-423-1DOE

Alternative Fuels Data Center World Wide Web Site: http://www.afdc.doe.gov
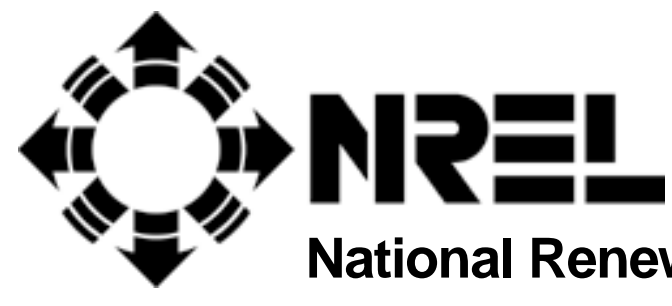

National Renewable Energy Laboratory

1617 Cole Boulevard

Golden, Colorado 80401-3393

NREL is a U.S. Department of Energy Laboratory

Operated by Midwest Research Institute $\bullet$ Battelle $\bullet$ Bechtel

Contract No. DE-AC36-98-G010337 


\section{Cummins Engine Company B5.9 Propane Engine Development, Certification, and Demonstration Project}

February 1997 - June 1998

The ADEPT Group, Inc. Los Angeles, California

NREL Technical Monitor: P. Norton

Prepared under Subcontract No. AAS-7-16609-02

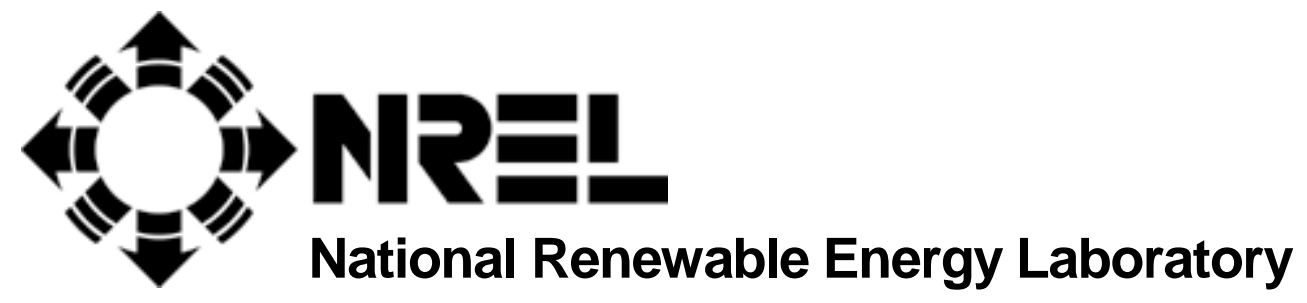

1617 Cole Boulevard

Golden, Colorado 80401-3393

NREL is a U.S. Department of Energy Laboratory

Operated by Midwest Research Institute $\bullet$ Battelle $\bullet$ Bechtel

Contract No. DE-AC36-98-G010337 


\section{NOTICE}

This report was prepared as an account of work sponsored by an agency of the United States government. Neither the United States government nor any agency thereof, nor any of their employees, makes any warranty, express or implied, or assumes any legal liability or responsibility for the accuracy, completeness, or usefulness of any information, apparatus, product, or process disclosed, or represents that its use would not infringe privately owned rights. Reference herein to any specific commercial product, process, or service by trade name, trademark, manufacturer, or otherwise does not necessarily constitute or imply its endorsement, recommendation, or favoring by the United States government or any agency thereof. The views and opinions of authors expressed herein do not necessarily state or reflect those of the United States government or any agency thereof.

Available to DOE and DOE contractors from:

Office of Scientific and Technical Information (OSTI)

P.O. Box 62

Oak Ridge, TN 37831

Prices available by calling 423-576-8401

Available to the public from:

National Technical Information Service (NTIS)

U.S. Department of Commerce

5285 Port Royal Road

Springfield, VA 22161

703-605-6000 or 800-553-6847

or

DOE Information Bridge

http://www.doe.gov/bridge/home.html

Printed on paper containing at least $50 \%$ wastepaper, including $20 \%$ postconsumer waste 


\section{Acknowledgments}

ADEPT wishes to acknowledge and thank the following parties, and the organizations they represent, for their contributions to the project tasks described in this report.

Cummins Engine Co.:

Engineering Test Services (Cummins):

Natural Resources Canada:

National Renewable Energy Laboratory:

Propane Vehicle Council:

Propane Gas Association of Canada:

South Coast Air Quality Management District:

Superior Propane:

Southwest Research Institute:

U.S. Department of Energy:
Dave Dunnuck, Vinod Duggal, Jim Branner Jr., Mike Haub, Mostafa Kamel, Jeff Mahon, Madison Rye, and Tina Vujovich

Joel Evans

Ian MacIntyre

Paul Norton

Joe Colaneri, Bob Myers

Bill Kurtze

Cindy Sullivan

Andris Bite

Kent Spreen

Steve Goguen

Many other parties, not identified above, were involved in various project phases beyond the scope of this report, but contributed to the project's success (such as the field test sites, Cummins' distributors, LPG/dealers, and marketers). 


\section{Acronyms and Abbreviations}

AFUP

AFV

bhp

BTDC

CARB

$\mathrm{CC}$

CCVS

CFFV

CFR

$\mathrm{CNG}$

$\mathrm{CO}$

$\mathrm{CR}$

CTC

CVS

$\mathrm{dBA}$

DF

DOE

ECM

EPA

ETS

$\mathrm{ft}$

$\mathrm{g} / \mathrm{bhp} / \mathrm{hr}$

GVW

$\mathrm{HC}$

HD

hp

ICM

$\mathrm{lb}$

LEV

LNG

LPG

NAA

NMHC

$\mathrm{NO}_{\mathrm{x}}$

NRCan

NREL

OEM

$\mathrm{O}_{2}$

PC

$\mathrm{PM}$

psig
Alternative Fuels Utilization Program

Alternative fuel vehicle

brake horsepower

below top dead center

California Air Resources Board

Clean Cities

closed crankcase ventilation system

Clean Fuel Fleet Vehicle

Consolidated Fuel Research

compressed natural gas

carbon monoxide

compression ratio

Cummins Technical Center

constant volume sampling

decibel attenuated

deterioration factor

U.S. Department of Energy

engine control module

U.S. Environmental Protection Agency

Engineering Test Services Facility (Cummins)

feet

grams per brake horsepower per hour

gross vehicle weight

hydrocarbons

heavy-duty

horsepower

ignition control module

pounds

low-emission vehicle

liquefied natural gas

liquefied petroleum gas

nonattainment area

non-methane hydrocarbons

oxides of nitrogen

Natural Resources Canada

National Renewable Energy Laboratory

original equipment manufacturer

oxygen

personal computer

particulate matter

pounds per square inch gauge 


\section{Acronyms and Abbreviations (concluded)}

PTO power take-off

PVC Propane Vehicle Council

rpm revolutions per minute

SCAQMD South Coast Air Quality Management District

SwRI

THC

Southwest Research Institute

total hydrocarbons

ULEV

ultra-low emission vehicle

WOT wide-open throttle 


\section{Contents}

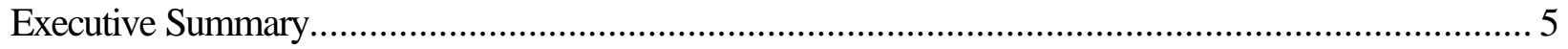

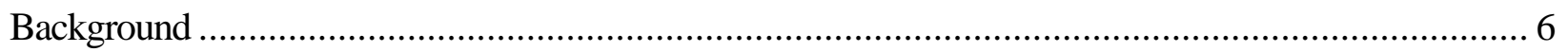

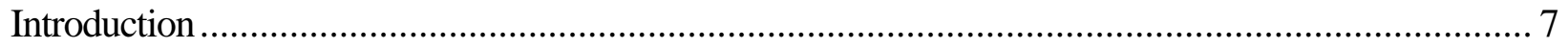

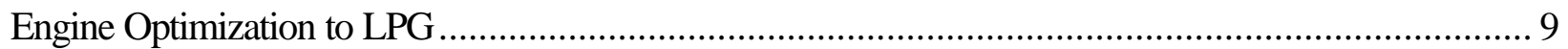

Engine Optimization and Refinements Resulting from Field Experience...................................... 15

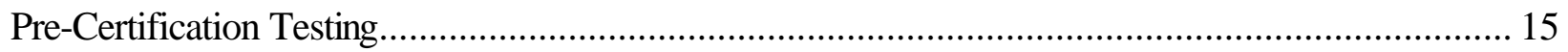

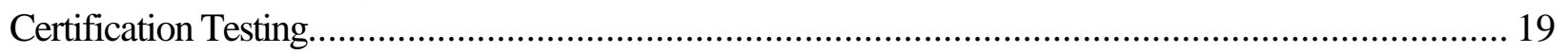

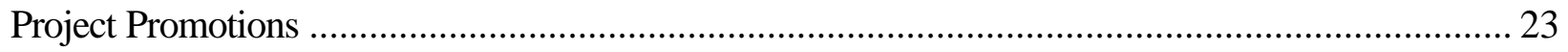

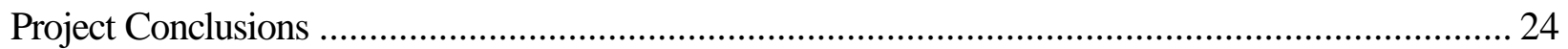

\section{List of Figures}

(Note: Figures provided courtesy of Cummins Engine Company)

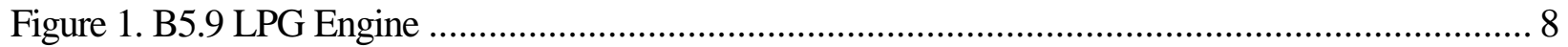

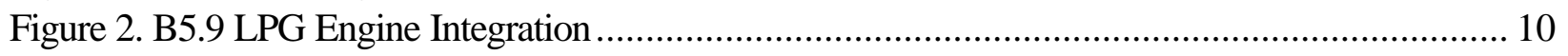

Figure 3. B5.9 LPG Engine - Fuel Delivery Sub-system........................................................ 11

Figure 4. Vehicle LPG Tank -- Cold Ambients Effect ......................................................... 13

Figure 5. B5.9 LPG Engine Electronic Control Sub-System ..................................................... 14

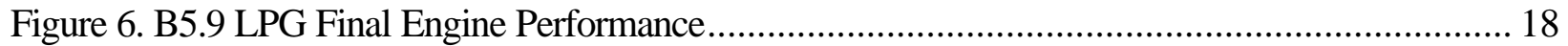

Figure 7. Noise Analysis - Baseline B5.9 Diesel Engine ..................................................... 18

Figure 8. 1998 B5.9 LPG EPA CFFV Certified Emissions ................................................. 21

Figure 9. 1998 B5.9 EPA HD Certified Emissions ............................................................. 22

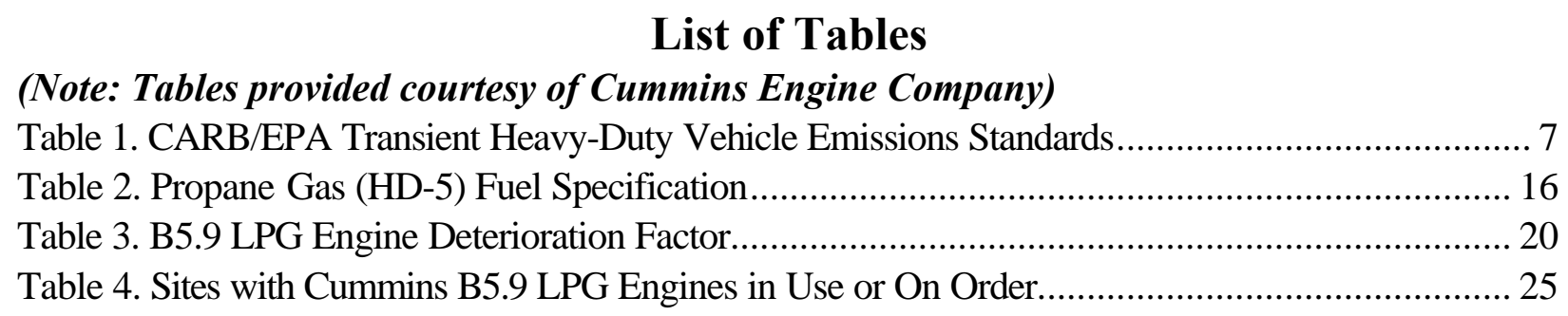




\section{Executive Summary}

In late 1994, the Cummins B5.9 Propane (LPG) ${ }^{1}$ Engine Development, Certification, and Demonstration Project was organized by Cummins Engine Company, the propane industry, and The ADEPT Group. Cummins began engine development in 1995 and continued through 1997, building on its extensive experience with natural gas engines, specifically the $\mathrm{B} 5.9 \mathrm{G}^{2}$. The objective of this project was to successfully develop and certify an LPG dedicated medium-duty original equipment manufacturer (OEM) engine that could be put into production (see Figure 1). This project was cofunded by Cummins, the National Renewable Energy Laboratory (NREL), Natural Resources Canada (NRCan), the Propane Vehicle Council (PVC), the South Coast Air Quality Management District (SCAQMD), and Superior Propane. Several field-test sites provided vehicles and staff to help demonstrate "field-test" and "market-seed" engines. ${ }^{3}$

The foundation for the B5.9LPG project was the B5.9G engine. The B5.9G development and certification program began in 1991. It was launched into production in 1994. More than 800 B5.9G engines are now in service in the United States and abroad. This engine is offered by more than 30 bus and truck OEMs. The B5.9 diesel version is used worldwide with millions sold since its introduction.

NREL funded two specific project tasks: (1) Task 1-Pre-Certification Testing and Engine Optimization and (2) Task 2-California Air Resources Board (CARB) and U.S. Environmental Protection Agency (EPA) Engine Certification. This report describes the conduct and completion of these two tasks.

The following personnel at the below locations conducted all testing and engine optimization activities:

- Cummins Alternative Fuel Division Engineering staff in the Cummins Technical Center (CTC) in Columbus, Indiana: Vinod Duggal, Jim Branner, Jr., Mostafa Kamel, Madison Rye, Mike Haub, Dave Dunnuck, and Jeff Mahon.

- Engineering Test Services (ETS) facility in Charleston, South Carolina: Joel Evans.

- Southwest Research Institute (SwRI) staff (lower tier subcontractor) in San Antonio, Texas: Kent Spreen.

ADEPT served as project manager and administrator of the NREL, PVC, and SCAQMD funds and as coordinator for one field-test site. ADEPT support personnel included: Alex Spataru, Alina Kulikowski-Tan, James Hendersen, Jeff Thayer, and Tracy Wilcox.

\footnotetext{
1 Also known as liquefied petroleum gases (LPG).

2 Natural Gas

3 "Field-test" engines were the first prototype engines put into demonstration. "Market-seed" engines were a preproduction engine where a chassis OEM was involved.
} 
Data for engine optimization were collected from laboratory facilities and from the field. During the project, Cummins logged more than 9,000 hours on 48 engines in various lab-testing activities and more than 300,000 miles in the field at 11 sites. In September 1997, Cummins launched the B5.9LPG into limited production. In May 1998, the engine was put into full production.

\section{Background}

NREL is the field manager for the U.S. Department of Energy (DOE) Alternative Fuels Utilization Program (AFUP), which sponsored the B5.9LPG engine project. AFUP's goal is to develop and advance technology that allows optimum use of alternative transportation fuels, while complying with modern constraints such as reduced vehicle emissions. For alternative fuels to be viable candidates to replace petroleum-based counterparts, it must be demonstrated that their impact on air quality will be no worse than that of existing fuels and preferably show characteristics that will improve air quality.

Because of the nation's continuing concern about air pollution, Congress enacted the Clean Air Act Amendments of 1990. The act's provisions have forced broad changes in fuels and vehicles. For example, reformulated gasolines, clean diesels, and alternative fuels are receiving wide attention as industry struggles to comply with the act. Also, to meet their air quality standards, many of the nonattainment areas (NAAs) across the country will need to increase their use of alternative fuels. Of the major transportation sectors, the medium-duty vehicle sector (e.g. package delivery vans, large pick-ups, and shuttle buses) may offer a good opportunity for urban emissions reduction because many of these vehicles are operated in urban environments. Therefore, additional research and development of alternative fuel, medium-duty engines and vehicles is important to DOE and NREL.

DOE projected that there were about 381,000 alternative fuel vehicles (AFVs) in use at the end of 1997. Out of these 271,000 operate on propane. This represents more than $71 \%$ of all the AFVs in the United States. In 1997 (in total gasoline equivalent gallons) LPG accounted for about $77 \%$ of all alternative transportation fuels used in the United States.

In light of federal and California emission reduction goals, the 1997 B5.9LPG engine certification target was the EPA Clean Fuel Fleet Vehicle (CFFV) ultra-low-emission vehicle (ULEV) certification and CARB Optional Low $\mathrm{NO}_{x}$ (see Table 1). The EPA CFFV program applies to fleets of 10 or more vehicles, which are centrally fueled or capable of being centrally fueled, in the 22 NAAs. For heavyduty vehicles $(8,500-26,000 \mathrm{lb}$ gross vehicle weight [GVW]), the requirement is $50 \%$ of new vehicles purchased starting in 1999. A low-emission vehicle (LEV) counts as 1.0 credit, whereas an ULEV vehicle counts as 1.87 credits. Heavy-duty (HD) vehicles greater than 26,000 lb GVW for these NAA fleets can generate credits; though not required to as part of this program.

Note that CARB LEV and ULEV emission standards do not apply to the B5.9LPG engine because it is not used in applications of less than 14,000 lb GVW. The CARB Optional Low $\mathrm{NO}_{\mathrm{x}}$ emissions levels 
refer to vehicle applications of $14,000 \mathrm{lb}$ GVW or higher. For 1997 the standard could be from 0-3.5 grams per horsepower-hour (g/bhp-hr) in 0.5 increments $\left(1.5 \mathrm{~g} / \mathrm{bhp}\right.$-hr below the current-year $\mathrm{NO}_{\mathrm{x}}$ emissions limit). For 1998, the standard is $4.0 \mathrm{~g} / \mathrm{bhp}-\mathrm{hr}$; thus, the maximum optional low $\mathrm{NO}_{\mathrm{x}}$ is 2.5 $\mathrm{g} / \mathrm{bhp}-\mathrm{hr}$. Table 1 gives further details.

Table 1. CARB/EPA Transient Heavy-Duty Vehicle Emissions Standards

\begin{tabular}{|l|c|c|c|c|c|}
\hline \multirow{2}{*}{$\begin{array}{l}\text { Emissions } \\
(\mathrm{g} / \mathrm{bhp}-\mathrm{hr})\end{array}$} & \multicolumn{3}{|c|}{ Emissions Standards } & \multicolumn{2}{c|}{ Emissions Certification } \\
\cline { 2 - 6 } & EPA CFFV LEV & EPA CFFV ULEV & CARB HD & 1997 B5.9LPG & 1998 B5.9LPG \\
\hline $\mathrm{NO}_{\mathrm{x}}$ & & & $5.0^{7}$ & 2.2 & 2.3 \\
\hline $\mathrm{THC}$ & & & 1.3 & 0.9 & 0.8 \\
\hline $\mathrm{NO}_{\mathrm{x}}+\mathrm{THC}$ & 3.8 & 2.5 & & 3.1 & 3.1 \\
\hline $\mathrm{PM}$ & 0.10 & 0.05 & 0.10 & 0.02 & 0.01 \\
\hline $\mathrm{CO}$ & 15.5 & 7.2 & 15.5 & 3.6 & 1.0 \\
\hline $\mathrm{HCHO}$ & & 0.025 & & & LEV \\
\hline EPA CFFV & & & & 2.5 & 2.5 \\
\hline CARB Low $\mathrm{NO}_{\mathrm{x}}$ & & & & & \\
\hline
\end{tabular}

\section{Introduction}

The B5.9G is a six-cylinder, in-line configuration, four-cycle engine with 150 to $230 \mathrm{hp}$. The overall B5.9 LPG engine development strategy was to:

- Build on the B5.9G engine experience, which uses a base diesel platform.

- Maximize sub-system commonality with the B5.9 diesel and natural gas models (ignition, controls and air/fuel management).

- Optimize LPG sub-systems: (a) fuel delivery, (b) power cylinder, (c) combustion performance, and (d) emissions.

- Obtain 1997 CARB/EPA certification.

The engine optimization and precertification testing process included the following elements:

- Complete engine functional specification.

- Refine and complete natural gas engine components modification for LPG and LPG-specific components.

- Refine and complete engine software calibration modifications (e.g., $\mathrm{O}_{2}$ sensor).

- Select and optimize LPG specific items (i.e., oxidation catalyst and integral vaporizer/regulator.)

\footnotetext{
496 inches maximum distance from the turbocharger exhaust outlet to the catalyst inlet.

${ }^{5} \mathrm{EPA}(>8,500 \mathrm{lbs}$ GVW), CARB (>14,000 lbs GVW)

${ }^{6}$ Closed crankcase ventilation system required by 1998 EPA Certification

${ }^{7}$ Optional low $\mathrm{NO}_{\mathrm{x}}(0-3.5$ in 0.5 increments for 1997; 0-2.5 for 1998)
} 
- Pre-certification testing and analysis:

Establish certification-testing parameters.

Test for performance ranges with HD-5 specification LPG fuel.

Test for mechanical development (including vibration, leakage, hydrostatic, and deformation) and durability (including 500 and 1,000 hours, and precertification transient emissions).

Figure 1 illustrates the B5.9 LPG engine.

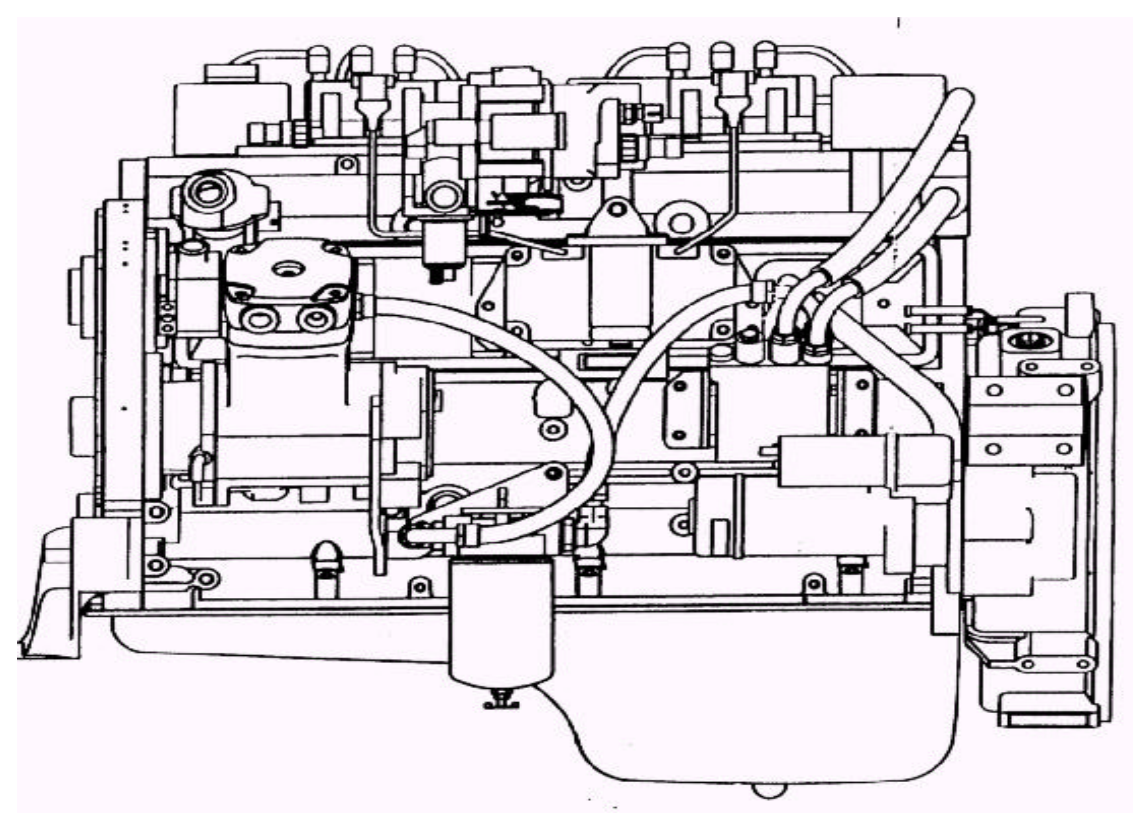

Figure 1. B5.9 LPG Engine

This engine was designed for use with HD-5 LPG specification fuel. Certification with and without an oxidation catalyst was planned, though Cummins expected (based on previous work) that a catalyst would be required to meet the total hydrocarbons (THC) ${ }^{8}$ requirement for CARB/EPA. Certification deterioration factor (DF) tests were not required because Cummins had an approved DF for a sparkignited, lean-burn natural gas engine - the B5.9 natural gas, upon which the B5.9LPG was designed. The DF is the same for a spark-ignited engine family (i.e., B5.9) independent of fuel type (compressed natural gas [CNG], liquefied natural gas [LNG], and LPG). This DF was based on a 1,200-hour engine test conducted at Cummins in 1994. The CARB/EPA (40 Consolidated Fuel Research [CFR] 86) certification requirements are as follows:

- One cold cycle (1/7 weighted)

- One hot cycle (6/7 weighted)

- Composite average result

- Established DF factor.

${ }^{8}$ This is an LPG-specific issue because of the chemical structure and hydrocarbon (HC) content of LPG. 
In 1997 Cummins conducted formal certification testing on B5.9LPG engines three times with engine analysis and data optimization between and after each test series:

- February 1997 at SwRI: Initial testing did not achieve desired emissions targets.

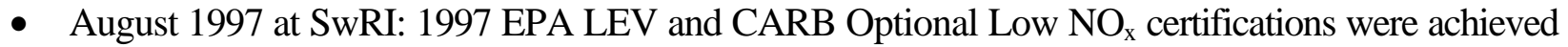
with an oxidation catalyst.

- November 1997: 1998 EPA CFFV LEV and CARB Optional Low $\mathrm{NO}_{\mathrm{x}}$ certification were successful.

The Task Discussion reviews the work conducted in the following sections: Engine Optimization to LPG, Optimization Refinements Resulting from Field Experience, Precertification Testing, and Certification Testing.

\section{Engine Optimization to LPG $^{9}$}

\section{Completion of Functional Specification for B5.9 LPG Engine}

The B5.9 LPG is a lean-burn, spark-ignited engine with electronic management. The engine's design targets for the B5.9 LPG operating on HD-5 LPG were:

- $\quad 195$ rated hp at 2,800 rpm and $420 \mathrm{ft}-\mathrm{lb}$ peak torque at 1,600 revolutions per minute (rpm)

- $285 \mathrm{ft}-\mathrm{lb}$ at $800 \mathrm{rpm}$ at wide open throttle

- ULEV targets (g/bhp-hr) with a catalyst: ${ }^{10}$ with $\mathrm{NO}_{\mathrm{x}}+\mathrm{THC} 2.5 ; \mathrm{CO}$ 7.2; and particulate matter (PM) 0.05 (zee Table 1)

- Integrated fuel handling and ignition subsystems (see Figures 2 and 3)

- Engine protection and PC-based diagnostics (see Figure 5)

- Engine-mounted controllers

- Compression ratio (CR) of 9:1

- Maximize parts commonality with B5.9G engine (only 10 new LPG-specific parts)

These targets were met with the exception of emissions (LEV, instead of ULEV) and rated horsepower speed (achieved at a lower speed of 2,600 rpm).

\footnotetext{
9 There are several references to suppliers throughout the report. ADEPT and Cummins are not presently authorized to identify them in this report. For further inquiries, please contact Cummins Alternative Fuels Group.

${ }^{10}$ A catalyst is required for the B5.9LPG to meet the heavy-duty THC standard.
} 


\section{Refinements and Completion of Modified Natural Gas Engine Components for LPG, LPG Specific Components, and Engine Software Calibration}

The B5.9 engine components listed below were added, modified, or optimized (or all three) to the LPG application.

- Pistons

- Integral vaporizer/regulator/shut-off valve

- Vaporizer coolant hoses

- Fuel hoses

- Fuel assembly housing

- Mass flow sensor

- Fuel metering valve

- Engine control module (ECM) software

- Engine wiring harness

- Catalyst

Two new B5.9G family enhancements were incorporated in the B5.9 LPG engine to maintain parts commonality: (1) a high-temperature exhaust manifold ${ }^{11}$ and (2) a revised fuel-metering valve. ${ }^{12}$ Figure 2 illustrates the B5.9 LPG subsystem engine integration, including those items specifically added for the LPG application.

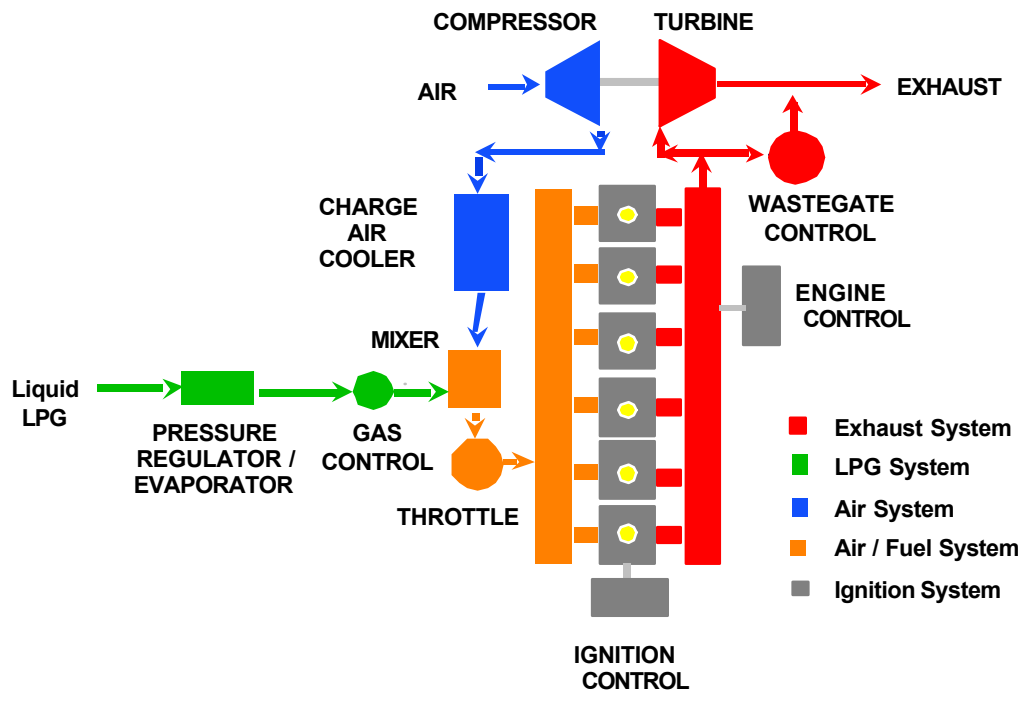

Figure 2. B5.9 LPG Engine Integration

\section{Piston/Combustion Chamber Design}

Cummins' evaluation of the engine operating margins (detonation) indicated a need for increased knock margin at rated power [195 hp at 2,800 rpm]. This optimization process led to rated horsepower

\footnotetext{
11 Initially released on the B5.9 diesel engine platform.

12 Initially released on the B5.9G engine platform.
} 
speed change from 2,800 to 2,600 rpm while governed speed was maintained at 2,800 rpm. The LPG-specific piston was also redesigned to lower the CR from 9.5:1 to 9:1 (the B5.9G CR is 10.5:1).

Cummins modified the piston compression ratio because of the lower octane rating of LPG compared to that of natural gas. The piston bowl geometry was modified to achieve a CR of 9:1 while meeting internal piston design standards. This modification also expanded the knock margin. The new piston was implemented for durability and field-test engine evaluation. Operating margin evaluation work continued throughout the certification period.

\section{Engine-Mounted Vaporizer/Regulator - LPG Specific Item ${ }^{13}$}

The combination vaporizer/pressure regulator design for performance and durability continued to be optimized with the supplier. Although the supplier produces vaporizer/regulators for other LPG engine applications, this effort is B5.9 LPG engine specific because of the engine's operating requirements (i.e., turbocharged and engine-mounted). This component was the primary reliability concern during performance and field tests. Figure 3 illustrates the sequence of fuel handling from the vehicle tank to the engine.

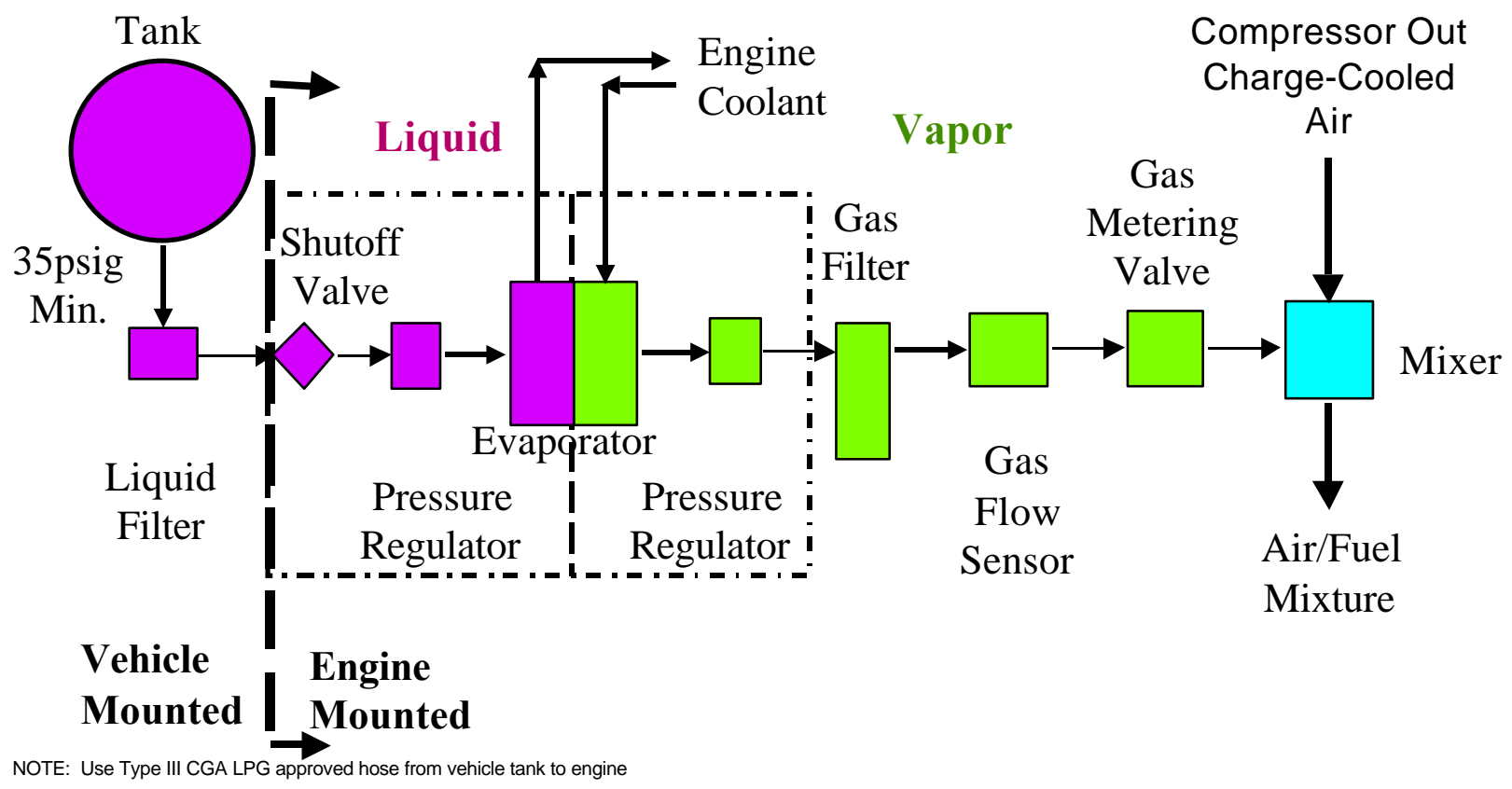

Figure 3. B5.9 LPG Engine - Fuel Delivery Sub-System

\section{Catalyst - LPG Specific Item}

Initially Cummins applied the B5.9G catalyst to the B5.9 LPG engine. This catalyst did not meet emissions reduction targets in the first phase of certification testing. Subsequently, Cummins selected an oxidation catalyst for the B5.9 LPG engine from its current supplier for the $\mathrm{C} 8.3 \mathrm{G}$ engine that provided

\footnotetext{
13 This item was added to the engine for the LPG application rather than a modification of an existing engine part.
} 
higher THC reduction efficiency than the B5.9G catalyst. See further discussion in the section entitled "Certification."

Cummins demonstrated the capability to meet EPA CFFV/ULEV emission levels (see Table 1) for the B5.9 LPG engine with an oxidation catalyst through preliminary steady-state and transient precertification emissions tests at CTC.

\section{Fuel-Metering Valve Technologies (Vapor Side-Fuel Plumbing)}

As a turbocharged spark-ignited engine with single-point gaseous fuel injection, the B5.9 LPG engine requires a minimum fuel supply pressure to the engine to reach rated performance. The minimum fuel supply pressure, with margin, was set at 35 pounds per square inch gauge (psig) to the upstream side of the shut off valve prior to the vaporizer/regulator. This 35-psig requirement was derived from an evaluation of LPG characteristics at low temperatures, flow-pressure losses through the engine's fuel system, and the need to overcome maximum turbocharger boost pressure rated horsepower for singlepoint fuel injection.

For a vehicle fuel system, saturated LPG tank pressure is a function of temperature. In cold-weather operation, a temperature could be reached where the fuel supply pressure to the engine cannot meet the 35-psig requirement (see Figure 4). At such temperatures, delivery of liquefied LPG in the engine affects the engine fuel supply and, therefore, engine performance. Because engine block water is used to vaporize the fuel, cold weather operation required special equipment such as heating blankets or a vehicle fuel system with a pump. ${ }^{14}$ The shaded region in Figure 4 highlights the region between minimum pressure supplied by the pump (35 psig line) and the LPG saturated pressure/temperature curve.

Vehicle and laboratory cold-weather startability tests ${ }^{15}$ at CTC demonstrated the capability of providing 35-psig minimum LPG supply to the engine. In March 1997, the engine started successfully at

- $32^{\circ} \mathrm{F}$ minimum ambient temperature, with an unpressurized vehicle fuel system

- $10^{\circ} \mathrm{F}$ ambient temperature, with an engine block heater and an unpressurized vehicle fuel system

- $-10^{\circ} \mathrm{F}$ ambient temperature, with a pressurized vehicle fuel system.

In April 1997, further vehicle and laboratory cold weather startability tests demonstrated the capability of successfully providing 35-psig minimum LPG supply at

- $32^{\circ} \mathrm{F}$ minimum ambient temperature, with an unpressurized vehicle fuel system

- $5^{\circ} \mathrm{F}$ ambient temperature, with engine block and oil pan heaters and an unpressurized vehicle fuel system

\footnotetext{
${ }^{14}$ For the B5.9LPG, the LPG must be sustained in a gaseous phase. As illustrated in Figure 4, cold weather conditions can cause a bi-phase fuel condition that would affect engine performance. This is a propane specific issue.

15 The CTC facility uses dedicated refrigerated test cells for cold temperature startability and performance tests.
} 
- $\quad-17^{\circ} \mathrm{F}$ ambient temperature, with a pressurized vehicle fuel system; engine warm up at idle was required to assure full rated power capability.

There were two reasons for the expansion in the test temperatures threshold: (1) the addition of an oil sump heater allowed a cold start of the engine at even lower temperatures, and (2) the discovery that the engine would start at ambient temperatures between $-17^{\circ} \mathrm{F}$ to $10^{\circ} \mathrm{F}$, but could not operate at full rated power. Additional cold-weather tests, which confirmed these test results, were conducted in June 1997.

Cummins held a meeting with a propane vehicle fuel system supplier to discuss the cold-weather requirements for the lean-burn, turbocharged B5.9 LPG engine. This supplier manufactured a pressurized vehicular fuel tank system that would meet the 35-psig liquid fuel supply requirement to the engine. A prototype of this system was used for Cummins cold-weather testing for a pressurized vehicle fuel storage system.

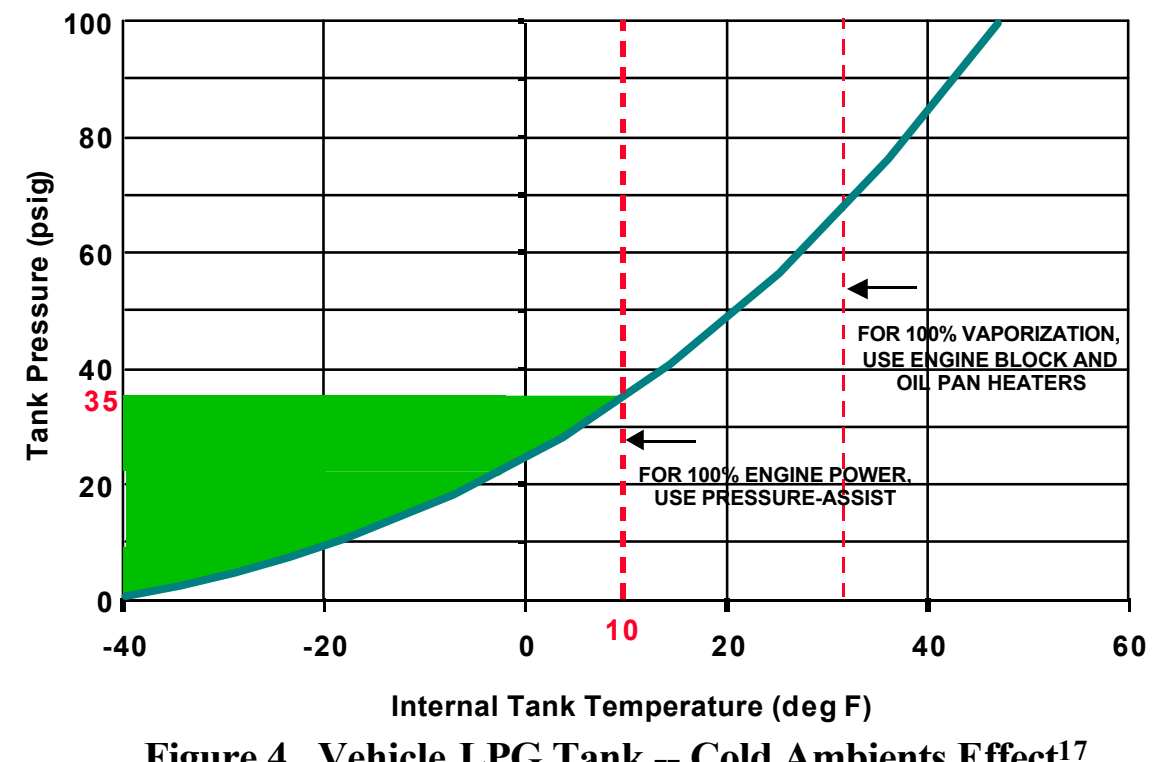

\section{ECM Software Recalibration}

Engine operating margins evaluation work resulted in a requirement to lower peak rated horsepower speed $(2,600 \mathrm{rpm})$ while maintaining governed speed at 2,800 rpm. The ECM software calibration was revised to tailor to optimum LPG operation. Components that required software table modifications were

- Air/fuel ratio

- Ignition timing

\footnotetext{
16 For the B5.9LPG, the LPG must be sustained in a gaseous phase. As illustrated in Figure 4, cold weather conditions can cause a bi-phase fuel condition that would affect engine performance. This is a propane specific issue. Previously used strategies to address this issue include on-board heating of the fuel.

17 Pressure assist refers to the use of a pump to deliver fuel versus an unpressurized fuel system.
} 
- Rated speed

- Turbocharger boost pressure

- Gas flow sensor.

The tasks for ECM software development included

- Concept engine controls

- Development engine controls

- Optimization of performance and emissions

- Production engine controls.

Figure 5 shows the ECM/ignition control module (ICM) interface and the various functions and subsystem controls.

This rated horsepower speed change and the piston revision implemented last spring provided the required detonation margin at rated power (based on validation tests conducted at CTC). The software calibration revision was downloaded into the ECM of all field-test and market-seed units, with no problems reported to date.

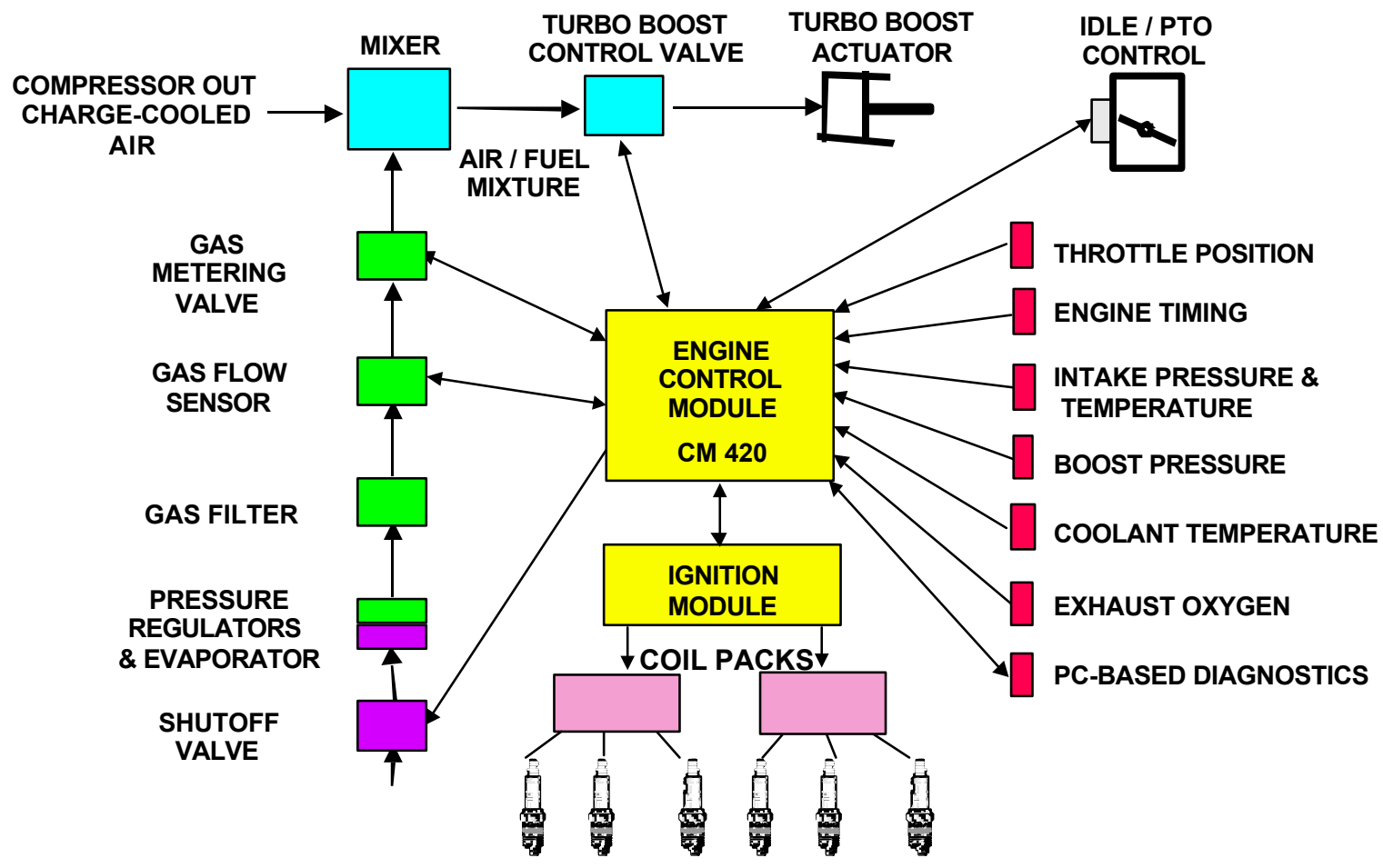

Figure 5. B5.9 LPG Engine Electronic Control Sub-System 


\section{Engine Optimization and Refinements Resulting from Field Experience}

\section{Engine Software Algorithm}

In March 1997, one field-test issue required software algorithm testing to validate a solution. All five LPG bobtail trucks' engines stalled occasionally in the field after completing power take-off (PTO) operation for off-loading LPG fuel while the engine was at 1,000 rpm. A temporary fix was provided during engine operation (modified driver procedures before and after PTO operation). The modified drivers' procedures included pressing the accelerator to increase the engine speed above idle speed before engaging in PTO.

Subsequently, an ECM software revision was validated in the laboratory and provided a permanent solution to engine stalling. The revision was downloaded into the engines' ECM in LPG bobtail applications.

\section{Other Data Collected from the Field}

Oil consumption data and analysis for the field-test vehicles showed equal results to fleets operating the B5.9G 195-hp engine. Cummins anticipated this outcome because the hardware affecting oil consumption is identical for both engine versions. No problems were found with wear metals, contaminant metals, additive metals, non-metallic components, or lube fluids.

B5.9 LPG engine shutdowns were observed in the field. These shutdowns were correlated with the following conditions: voltage drops in the ECM/ICM, failure of the regulator vaporizer, and front-cover and rear-cover gasket failure. Analysis of these occurrences is ongoing. Detail at a later date may be obtained from the Alternative Fuels Division of Cummins Engine Company. In the ECM/ICM voltage drop incidences there appear to be electric system instabilities and faulty wiring. Also, voltage swings are experienced in the transit shuttle application itself. 18

\section{Pre-Certification Testing}

From July 1997 to August 1997 two preproduction B5.9 LPG engines were subjected to precertification tests (steady-state emissions), performance and emissions optimization, and constant volume sampling (CVS) transient emissions analysis. These tests, in addition to field-test vehicle performance (driveability) tests, served to optimize the engine for limited production, scheduled for the third quarter of 1997. All precertification tests were conducted at CTC.

Performance, durability, and field-test engine data were used to develop an optimum performance and emissions baseline for optimization based on both steady-state and CVS transient emissions tests. Enhancements were validated in the laboratory on the performance and durability of the engines, as well as in vehicles via field test engines.

${ }^{18}$ For further detail please contact the Alternative Fuels Group of Cummins Engine Co. 
All testing was conducted on HD-5 specific LPG. The LPG had the following component percentages: 94.6-95.8\% propane, 0.3-0.8\% propene 0.4-1.6\% iso-butane, and 0.1-0.2\% n-butane. A contract propane marketer that supplies LPG fuel for Cummins CTC forklifts supplied the HD-5 specification fuel. Cummins qualified the contents of the fuel in a CTC laboratory analysis. The HD-5 fuel specification is shown in Table 2.

Table 2. Propane Gas (HD-5) Fuel Specification

\begin{tabular}{|lcc|}
\hline \multicolumn{1}{|c}{ Constituents } & Requirement & Test Method \\
Propane, volume \% & 90.0 Minimum & ASTM D 2163 \\
Propylene, volume \% & 5.0 Maximum & ASTM D 2163 \\
Butane \& Heavier, volume \% & 2.5 Maximum & ASTM D 2163 \\
Hydrogen Sulfide & Pass & ASTM D 2420 \\
Total Sulfur, ppmw & 123 & ASTM D 2784 \\
Oxygen, weight \% & 0.5 Maximum & ASTM D 1945 \\
$\mathrm{CO}_{2}+\mathrm{N}_{2}$ & 3.0 Maximum & ASTM D 1945 \\
\hline
\end{tabular}

(Note: California specification for propane is $85 \% \mathrm{~min}$. by volume)

An area of focus was the evaluation of combustion operating margins for rated power of $195 \mathrm{hp}$. Adequate knock margin was not initially achieved. Engine performance and combustion optimization work increased the detonation margin at rated power while preserving engine performance targets. (See Figure 6 and the Piston/Combustion Chamber Design discussion.)

As part of preparing for certification testing Cummins conducted the following tests:

1. Mechanical development testing included

- Vibration

- Leak

- Hydrostatic.

2. Performance development tests included

- 500-hour "hot box" (elevated system temperatures)

- 500-hour thermal cycle

- 500-hour hot endurance. 
3. Additional development tests conducted

- 1,000-hour peak power overload

- 250-hour overload

- 250-hour idle speed.

For performance development tests, the cylinder head was instrumented for dynamic in-cylinder \#1 pressure measurement for some of the performance and development engines. The engine was also instrumented for the following parameters:

$\begin{array}{lll}\text {-Engine speed } & \text {-Fuel temp } & \text {-Fuel pressure } \\ \text {-Torque } & \text {-Intake temp. } & \text {-Intake pressure } \\ \text {-Throttle position } & \text {-Exhaust gas oxygen } & \text {-Turbine inlet temp. } \\ \text {-Fuel flow } & \text {-Air flow } & \text {-Turbine inlet pressure } \\ \text {-Blowby pressure } & \text {-Exhaust port temp. } & \text {-Exhaust port pressure } \\ \text {-Compressor out-pressure } & \text {-Compressor outlet temp. }\end{array}$

A Cummins proprietary high-speed data acquisition system was used in conjunction with the in-cylinder pressure transducer to analyze:
-Combustion duration
-Coefficient of variance
-Rate of combustion
-Start of combustion.

The tendency for knock and misfire and the engine heat release were evaluated using this engine data and to calculate:
-Air/fuel ratio
-Power
-Brake specific fuel consumption (bsfc)
-Thermal efficiency.

Cummins inspected the test engines for pitting, scuffing, abrasion, and excessive wear through visual inspection and micromeasurement and found no problems. Areas under inspection for wear were found to be within base engine specifications. In these development areas a variety of data-based analyses were compared to results for the B5.9G and diesel engines using Cummins' internal standards. No major issues were raised during these tests. Some of the major components analyzed for reliability and durability were:

-Cylinder head and overhead

-Fuel handling sub-system

-Crankshaft and bearings

-Ignition subsystem

-Power cylinder
-Spark plugs

-Turbocharger

-Camshaft and bearings

-Other base diesel/natural gas components. 
Figure 6 illustrates the final performance curve resulting from the above testing and optimization. The dash line denotes stoichiometric gasoline LPG conversions torque peak capability of similar rated HP.

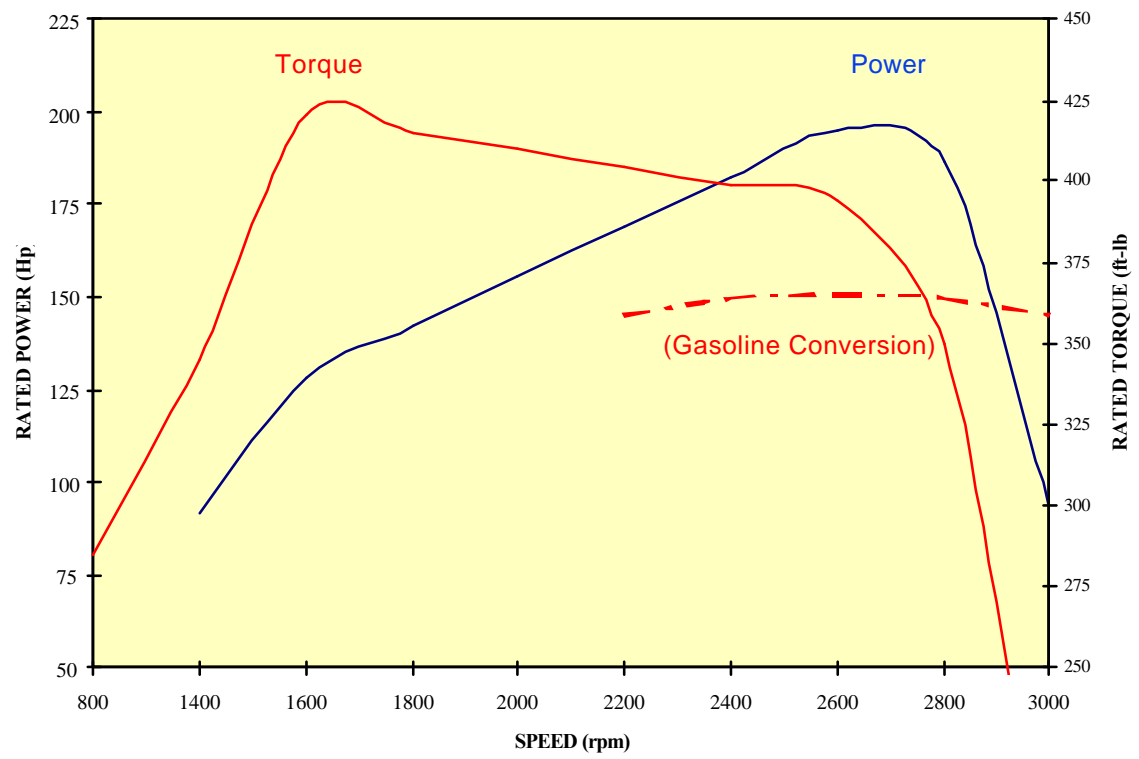

Figure 6. B5.9 LPG Final Engine Performance

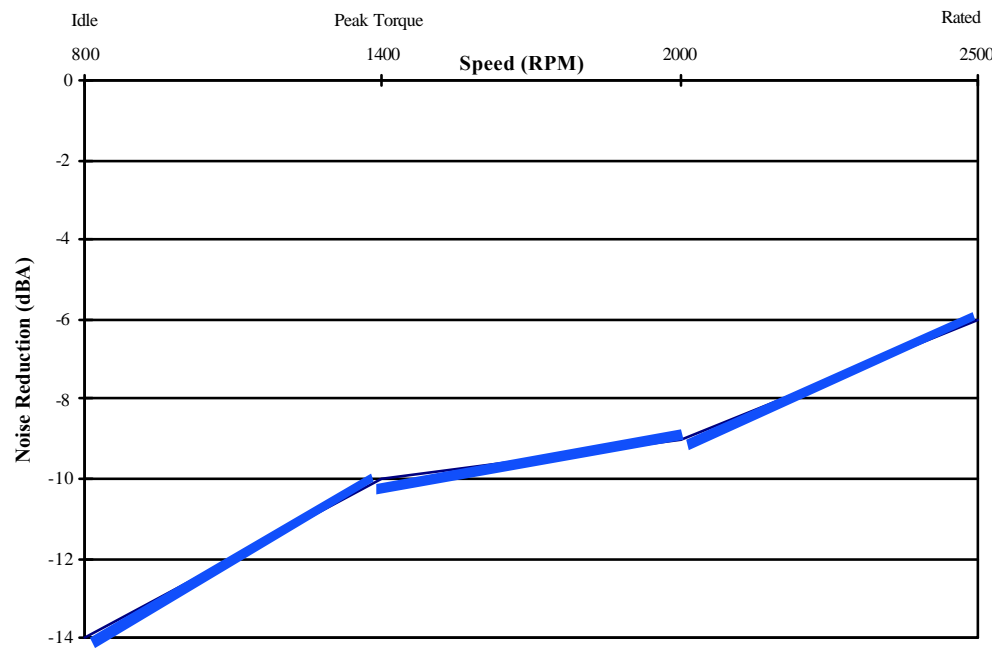

Figure 7. Noise Analysis - Baseline B5.9 Diesel Engine 


\section{Noise Testing}

As part of its engine development program (but not part of the NREL project contract) Cummins conducted engine noise testing. A one-meter free-field noise measurement, per SAEJ1074, showed a significant noise reduction along the full-load torque curve in comparison to a B5.9 diesel (see Figure 7).

\section{Certification Testing}

The three certification tests will be described as Phases I-III.

Cummins selected SwRI as the testing subcontractor based on an established and successful history with SwRI and because the CTC test facilities are not EPA-certified for testing spark-ignition engines. The team that conducted and completed the certification program included the following members:

- Cummins: Vinod Duggal, Jim Branner Jr., Mostafa Kamel, Jeff Mahon, and Dave Dunnuck.

- SwRI: Kent Spreen.

Tests conducted at SwRI were completed in a test cell equipped and calibrated to perform the EPA Heavy-Duty Engine Transient Federal Test Procedure CFR 40 No. 86. The LPG test fuel had the following components: $94.3 \%$ propane, $3.8 \%$ propene, and $1.9 \%$ n-butane. ${ }^{19}$ No testing was conducted without a catalyst.

Cummins did not conduct a DF test on the B5.9 LPG engine because there was an approved DF for the B5.9G. The premise for DF testing is to determine how various hardware and controls will deteriorate over a period of useful emissions life. The natural gas engine DF can be applied to the B5.9 LPG engine because the combustion processes, hardware design, and control principles are the same for both engines. The engines differ in the amount of fuel used, timing of combustion, and compression ratio or burn rates. The natural gas and LPG engines share the same ignition systems, fuel handling, air/fuel ratio control hardware, logic and control subsystems. The catalytic converters both include the same wash coat (catalytic surface), although the LPG engine catalyst is larger for the greater surface area needed for total HC control instead of only NMHC required for natural gas engines. This DF was based on a 1,200-hour engine test. The DF for the B5.9LPG engine is shown in Table 3.

${ }^{19}$ For information about test fuel sources contact the Alternative Fuels Group of Cummins Engine Co. 
Table 3. B5.9 LPG Engine Deterioration Factor

\begin{tabular}{|c|c|c|}
\hline Pollutant & $\begin{array}{c}\text { EPA } \\
\text { DF }\end{array}$ & $\begin{array}{c}\text { CARB } \\
\text { DF }\end{array}$ \\
\hline NO $_{\mathbf{x}}$ & 1.007 & 1.007 \\
\hline THC & 1.000 & 1.000 \\
\hline CO & 13.935 & 13.935 \\
\hline PM & 1.000 & 1.000 \\
\hline
\end{tabular}

The DF for carbon monoxide (CO) is relatively large because the $\mathrm{CO}$ emissions out of the oxidation catalyst are extremely low. At such low CO levels, measurement variability is high, and small changes in emission levels created a steep slope for the DF analysis. DFs are based on the slope of catalyst deterioration over time which, in the case of $\mathrm{CO}$, resulted in a relatively high $\mathrm{DF}$.

\section{Phase I}

The certification B5.9 LPG engine was built at the Cummins Rocky Mount, North Carolina, plant to utilize the manufacturing process system prototyping (e.g., customer order entry, engine assembly, software download, and engine test). The 120-hour certification-conditioning test of the engine and oxidation catalyst was completed at CTC. Subsequently, the engine was shipped to SwRI where an engine control problem (i.e., excessive vibration of the fuel control valve) occurred during preparation for emission certification testing. The engine was shipped back to Cummins for further troubleshooting.

The certification test was rescheduled after successful testing at Cummins. The engine control problem reoccurred at SwRI. Further trouble-shooting by Cummins staff at SwRI revealed that a solid-engine test cell mounting arrangement at SwRI caused excessive vibrations, which induced the fuel-system control problem. Soft-mounting of the engine in the SwRI test cell resolved the excessive engine vibration of the fuel control valve. The certification test was rescheduled and completed in February 1997. The results indicated that the B5.9 LPG engine with the catalyst failed to meet CARB/EPA heavy-duty certification because of THC emissions $(1.3 \mathrm{~g} / \mathrm{bhp} / \mathrm{hr})$.

Cummins rescheduled a second certification test for July 1997 once they completed a thorough emissions failure analysis; combustion operating margins evaluation, and performance/emissions optimization at CTC. Data analysis to understand certification test failure was conducted from March to June 1997. It revealed that:

- The engine was out of the rated power production specification (>5\% limit), thus producing higher than expected THC.

- The engine catalyst was located too far from the engine exhaust outlet, resulting in reduced catalyst THC effectiveness.

- LPG fuel caused higher THC emissions than natural gas. 
A CARB/EPA emissions certification plan for the second series of certification testing was prepared in April 1997 (see Appendix 1).

Cummins continued to optimize emissions and performance to assure $\mathrm{NO}_{\mathrm{x}}$ and $\mathrm{THC}$ emissions met EPA CFFV targets. Because of SwRI test-cell availability constraints, certification testing was delayed until August 1997.

\section{Phase II}

In July 1997, transient emissions tests conducted at CTC showed capability of meeting EPA CFFV and CARB Optional Low- $\mathrm{NO}_{\mathrm{x}}$ emission levels with the latest production version of the B5.9 LPG. Cummins reduced the maximum catalyst distance from the turbocharger outlet from 155 inches to 96 inches for cold start HC reduction. The second certification test with a production B5.9 LPG engine was scheduled for August 1997 at SwRI. Two changes were applied to the B.9 LPG engine: (1) the CR was changed from 9.5:1 to $9.0: 1$, and (2) the B5.9G catalyst was replaced with the C8.3G catalyst.

In August 1997, the 120-hour engine and catalytic converter conditioning test for certification was completed at ETS. Subsequently, the second engine CARB/EPA emissions certification tests were completed at SwRI. These tests were conducted on a production B5.9LPG engine, which included ECM software calibration revision, described earlier. Cummins submitted its applications for 1997 CARB and EPA emissions certificates. The certification data, with deterioration factors and the regulated EPA CFFV emission standards, are described in Table 1.

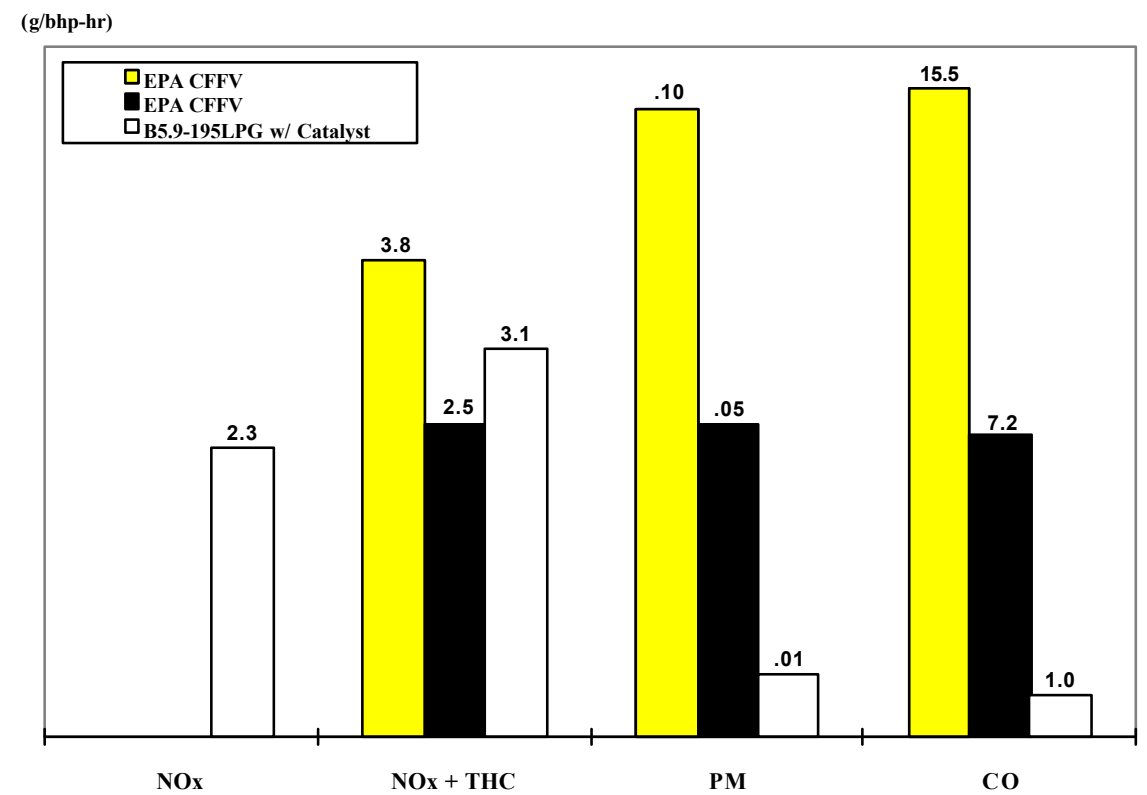

Figure 8. 1998 B5.9 LPG EPA CFFV Certified Emissions 
In September 1997, Cummins received the EPA CFFV LEV certificate for the B5.9 LPG engine with a catalytic converter (see Appendix 2 for documentation). The B5.9 LPG was the first dedicated heavyduty spark-ignited LPG engine to receive EPA CFFV LEV certification. Cummins' target for this program was the EPA CFFV ULEV standard. A LPG engine must certify to a total hydrocarbon (THC) emission level while a natural gas engine has the advantage of certifying to a non-methane hydrocarbon (NMHC) emission level.

In October 1997, Cummins received the CARB Optional Low NO $\mathrm{N}_{\mathrm{x}}(2.5 \mathrm{~g} / \mathrm{bhp}$-hr) certificate for the B5.9 LPG engine with a catalytic converter (see Appendices for documentation). The B5.9 LPG was the first dedicated heavy-duty spark-ignited propane engine to receive the CARB Optional Low $\mathrm{NO}_{\mathrm{x}}$ certification. Cummins planned to recertify the B5.9 LPG engine with close crankcase ventilation

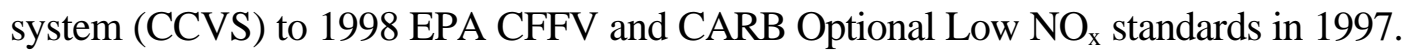

\section{Phase III}

In November 1997, Cummins completed the emission certification 120-hour conditioning tests at ETS on the B5.9 LPG engine with a production CCVS catalyst. This is an EPA requirement for 1998 certification for heavy-duty spark ignited engines and was not part of the NREL funded contract. Subsequently Cummins completed the 1998 EPA and CARB emissions certification tests at SwRI for the B5.9 LPG engine with CCVS. Cummins received emission certification from EPA and CARB for 1998 in December 1997. These results are shown in Figure 8 in comparison to the EPA CFFV ULEV and LEV standards, and in Figure 9 in comparison to the diesel engine. See Table 1 for the test results with DF.

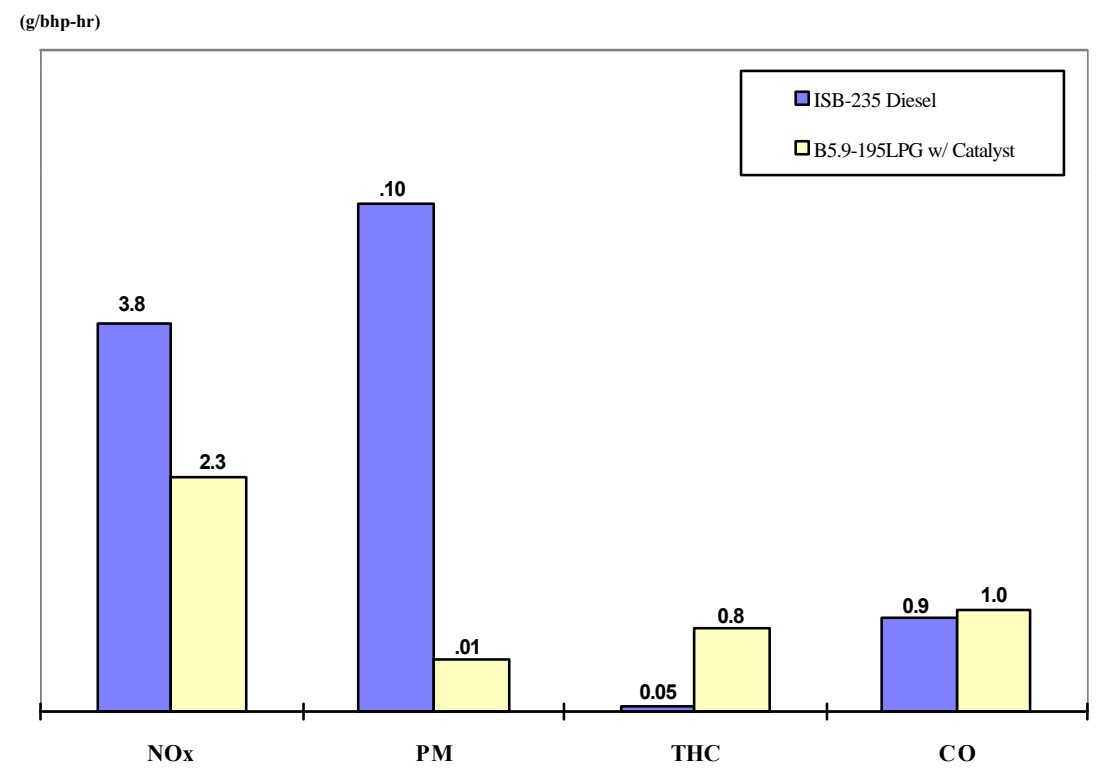

Figure 9. 1998 B5.9 EPA HD Certified Emissions 


\section{Project Promotions}

Throughout the project, ADEPT and Cummins promoted the project on various fronts. Below is a list of media articles about the project (See Appendix 3 for full text of articles.)

- Passenger Transport article entitled: “San Antonio System to Add 283 New Vehicles by 2002," March 1998.

- Butane Propane News article, re: City of Pasadena field site, June 1997.

- School Transportation News, article "Propane Gas Bus Popularity Increasing in Texas," August 1997.

- Cummins B5.9LPG engine press release (November 1997).

- Excerpt from AQMD Annual Report 1997.

Cummins and PVC jointly sponsored a campaign to display the B5.9 LPG engine at various events around North America. The events are listed in chronological order

- Technical presentation and engine display at the Propane Vehicle Magazine Conference (Orlando, FL) February 2-4, 1997.

- $\quad$ Engine display at the Midwest LPGA Trade Show (Indianapolis, IN) March 8-10, 1997.

- Ottawa Truck Commando 30-yard spotter with engine display at the Truck Maintenance Council Show, March 1997, then transferred to a Los Angeles dealer for customer demonstrations.

- Engine display at the Southeast National Propane Gas Association Trade Show (Atlanta, GA), April 6-8, 1997.

- Engine and Suburban FL70 B5.9LPG field-test truck display at the Western LPG Trade Show (San Diego, CA), April 24-26, 1997.

- Technical presentation and B5.9LPG engine display at the Windsor Alternate Fuels Conference (Windsor, Ontario, Canada), June 8-10, 1997.

- Engine display at the Oklahoma Pupil Transportation Conference (Oklahoma City, OK), June 811, 1997.

- Engine and demonstration vehicle display at the DOE Clean Cities (CC) Conference (Long Beach, CA), June 25-26, 1997.

- Engine display at the DOE CC Regional Conference (St. Louis, Missouri), July 30, 1997.

- Engine display at Southwest Propane Gas Trade Show and Convention (Dallas, TX), August 1920, 1997.

- Engine display at the DOE Regional CC Conference (Atlanta, GA), September 4, 1997.

- Engine display at the NPGA Trade Show and Convention (Providence, RI), September 26-28, 1997.

- Engine display at the National Association of Pupil Transportation (school bus) Conference (Indianapolis, IN), November 4-5, 1997.

- Technical presentation at the SCAQMD Technology Advancement Office Conference, December 4, 1997.

- Technical presentation and engine display at the Propane Vehicle Magazine Conference, February $11,1998$. 
- Engine display at the Southeast21 LPG Conference (Atlanta, GA), April 5-7, 1998.

- Engine display at the Midwest LPG Conference (Indianapolis, IN), April 25-27, 1998.

- Engine display for the Southwest LPG Conference (Dallas, TX), May 11-12 1998.

- Technical presentation and engine display for the DOE CC Conference (Washington, D.C.), May 31-June 3, 1998.

ADEPT and Cummins worked jointly to promote the use of the engine at additional sites. In Texas three sites are in development. Many more have started throughout the United States, Australia, and Mexico as a result of Cummins promotions. Table 4 shows the sites that have B5.9 LPG engines in use or on order.

\section{Project Conclusions}

This project was successful in that it resulted in an alternative fuel engine product that has the following attributes:

- Competitive fuel economy 22

- PC based diagnostics (INSITE software)

- Minimum engine life to overhaul of 300,000 miles $^{23}$

- Two year warranty with unlimited mileage

- CARB/EPA emissions warranty for five years or 100,000 miles with and without a catalyst. (LEV levels with catalyst only).

- B5.9 LPG offered by the following OEMs: Champion, El Dorado, Freightliner, Hoist, Ottawa, Spartan, and United Tractor.

The engine optimization and precertification tests for the B5.9LPG project were completed and met the EPA LEV and CARB Optional Low $\mathrm{NO}_{x}$ certification standards. As illustrated in Tables 1 and 3 and Figures 8 and 9, the $\mathrm{PM}$ and $\mathrm{CO}$ emissions are very low, with $\mathrm{NO}_{\mathrm{x}}$ emissions substantially low. The ULEV emissions target was not met due to the challenges of higher levels of total HC. In addition to HC content, LPG's high heat of combustion may yield higher emissions. Oxidizing catalysts will continue to be required to meet increasingly stringent emission standards. A heavy-duty LPG spark-ignited engine must meet a THC requirement whereas the natural gas engine is required to meet a NMHC standard. Cummins met the other B5.9LPG program deliverablesB5.9LPG engine shutdowns were observed in the field. These shutdowns were correlated with the following conditions: voltage drops in the $\mathrm{ECM} / \mathrm{ICM}$, failure

\footnotetext{
${ }^{21}$ Both ADEPT and Cummins conducted the presentation.

22 Per Cummins' comparisons to light-duty gasoline engine LPG conversions. Field test data, from Suburban Propane, shows 1.75-2.0:1 fuel consumption advantage of B5.9LPG vehicles versus LPG conversion vehicles in similar duty cycles.

${ }^{23}$ Engine life to overhaul is based on the expected life of the bottom-end components - crankshaft, camshaft, bearings, etc. for which 300,000 miles is the expectation. Although B5.9LPG engine experience is limited, Cummins L10G engine life experience lends to their expectation that B5.9LPG engine life will be longer than with diesel. This is predominantly due to the lack of soot or fuel in oil and lower thermal cycling of the engine over the operating range.
} 
Table 4. Sites with Cummins B5.9 LPG Engines in Use or On Order

OEM/User Field Tests

\begin{tabular}{|c|c|c|c|c|c|}
\hline Customer & Location & OEM & Application & Qty & Status (Miles) \\
\hline Suburban Propane & Sacramento Area & $\begin{array}{l}\text { Freightliner FL 70, } \\
\text { Repowers }\end{array}$ & LPG Bobtail & 4 & $\begin{array}{l}38,200 \text { - Unit \#1 } \\
53,200 \text { - Unit \#2 } \\
45,500 \text { - Unit \#3 } \\
36,400 \text { - Unit \#4 }\end{array}$ \\
\hline Superior Propane & Toronto, Canada & FL 80 - Repower & LPG Bobtail & 1 & 33,300 \\
\hline Western Transit & Pinole, $\mathrm{CA}$ & Thomas, Repowers & Shuttle Bus & $\begin{array}{c}2 \\
\text { Total:7 }\end{array}$ & $\begin{array}{l}56,700 \text { - Unit \#1 } \\
63,000 \text { - Unit \#2 }\end{array}$ \\
\hline
\end{tabular}

\begin{tabular}{|l|l|l|l|c|l|}
\hline Customer & Location & OEM & Application & Qty & Status (Miles) \\
\hline Delta Liquid Energy & Paso Robles, CA & Freightliner FL 70 & LPG Bobtail & 1 & 9,700 \\
\hline City of Pasadena & California & $\begin{array}{l}\text { Bluebird Q Bus, } \\
\text { Repowers }\end{array}$ & Shuttle Bus & 2 & $\begin{array}{l}27,100-\text { Unit \#1 } \\
12,300-\text { Unit \#2 }\end{array}$ \\
\hline UPS & Minneapolis, MN & Ottawa Truck & Yard Spotter & 1 & In Service \\
\hline Ranger Die Casting & Lynwood, CA & Freightliner FL 70 & LPG Bobtail & 1 & 9,000 \\
& & & Total:5 & \\
\hline
\end{tabular}

\begin{tabular}{|c|c|c|c|c|c|}
\hline \multicolumn{6}{|c|}{ Limited Production } \\
\hline Customer & Location & OEM & Application & Qty & Status (Miles) \\
\hline Allegheny Steel & New Castle, IN & Hoist Lifttruck & MD Forklift & 1 & In Service \\
\hline Allied Signal & Albuquerque, NM & Ottawa Truck & Yard Spotter & 1 & In Service \\
\hline Automotriz Uribe & Mexico City & Freightliner FL70 & Regional Delivery & 1 & In Service \\
\hline City of Santa Rosa & California & Freightliner FL70 & Regional Delivery & 1 & In Service \\
\hline CC Ind. School Dist. & Corpus Christi, TX & Blue Bird, Repower & School Bus & 1 & Planned \\
\hline CC Regional Transit & Corpus Christi, TX & Champion/Spartan & Shuttle Bus & 6 & On Order \\
\hline CC Regional Transit & Corpus Christi, TX & Repowers & Shuttle Bus & 3 & 1 On Order \\
\hline Delta Liquid Energy & Paso Robles, CA & Freightliner FL70 & LPG Bobtail Deliv. & 1 & Operational \\
\hline Elgas & Australia & Freightliner FL80 & Regional Delivery & 1 & Operational \\
\hline FEMSA (Coca Cola) & Mexico City & Freightliner FL70 & Regional Delivery & 1 & In Service \\
\hline Garber Post & Montgomery, IN & Ottawa Truck & Yard Spotter & 1 & In Service \\
\hline Kleenheat Gas & Australia & Freightliner FL80 & Regional Delivery & 1 & Operational \\
\hline LA DoT & Los Angeles, CA & El Dorado & Shuttle Bus & 30 & 30 In Service \\
\hline LA DoT & Los Angeles, CA & El Dorado & Shuttle Bus & 17 & On Order \\
\hline L.A. Murphy & Australia & Freightliner FL80 & Regional Delivery & 1 & Operational \\
\hline Northwest Trek Tram & Tacoma, WA & AAI-ACL/Spartan & Shuttle Bus & 2 & Engines Installed \\
\hline Oneil Gas & Choudrant, LA & Freightliner FL70 & LPG Bobtail Deliv. & 4 & Planned \\
\hline Paratransit & Sacramento, CA & Thomas Repowers & Shuttle Bus & 2 & Planned \\
\hline Solar Turbines & San Diego, CA & United Tractor & Yard Tug & 1 & In Service \\
\hline UPS & Minneapolis, MN & Ottawa Truck & Yard Spotter & 4 & In Service \\
\hline Various Customers & Not Available & Ottowa Truck & Yard Spotter & 8 & 2 Engines Shipped \\
\hline Various Customers & Not Available & Freightliner FL70 & Not Available & 3 & On Order \\
\hline VIA Transit & San Antonio, TX & Trolley & Shuttle Bus & 15 & Planned \\
\hline VIA Transit & San Antonio, TX & Champion/Spartan & Shuttle Bus & 66 & On Order \\
\hline VIA Transit & San Antonio, TX & Chance Coach & Trolley & 5 & Planned \\
\hline Western Propane & Santa Maria, CA & Freightliner FL70 & LPG Bobtail & 1 & Operational \\
\hline Western Transit & Pinole, CA & Thomas, Repowers & Shuttle Bus & 2 & In Service \\
\hline White River Dist. & TBD & Freightliner FL70 & LPG Bobtail Deliv. & 1 & Planned \\
\hline & & & Total: & 181 & \\
\hline
\end{tabular}


of the regulator vaporizer, and a front-cover and rear-cover gasket failure. Analysis of these occurrences is ongoing. Detail at a later date may be obtained from the Alternative Fuels Division of Cummins Engine Company.

In light of the HD-5 fuel specification, regular fuel testing by fleet operators is critical. Maintenance of HD-5 fuel quality is a requirement of B5.9 LPG warranty service. Even though all the LPG suppliers involved in this project made efforts to ensure HD- 5 compliance, field-testing indicated a wider range of fuel quality was supplied.

Additional research and development are recommended in the following areas:

- EPA CFFV ULEV capability

- Wider range fuel capability for combustion, performance, and emissions

- Parts supplier research and development to increase performance and durability of LPG specific parts

- Regulator vaporizer issues remain to be completely resolved

- An octane sensor could help further LPG engine design. Such a sensor, as part of ECM control, can advise actual fuel quality of the charge about to be introduced in the combustion chamber (an engine with known octane value input to its ECM allows for the option to adjust certain combustion control parameters like air/fuel ratio or ignition timing, or both). Thus the engine can be more tolerant of a broader range of LPG fuel.

- On-board fuel supply sub-systems and components require further research and development. For instance, an accurate LPG fuel level gauge is needed.

Additional marketing/promotion activities are recommended to:

- Increase the number of OEMs offering the engine.

- Increase awareness of this engine's availability on international markets.

In summary, this project was a success in that it fostered an engine that met engine performance targets while significantly reducing emissions. The engine development program illuminated critical design differences between natural gas and LPG engines. Further research and development is needed for LPG-specific components provided by outside suppliers.

In its first year of production, Cummins has received almost 200 orders. Warranty service experience for this engine will not be known for some time but is expected to be similar to the B5.9G engine. 


\section{The ADEPT Group, Inc.}

NREL Subcontract No. AAS-7-16609-02 under Prime Contract No. DE-AC36-83CH10093

"Cummins Engine Co. B5.9 Propane Engine Development, Certification, and Demonstration Project"

Subcontractor: The ADEPT Group, Inc.; Lower-Tier Subcontractor: Cummins Engine Co.

Final Technical Report 


\section{Cummins 6B Propane Engine Development, Certification \& Demonstraton Project}

\section{ARB / EPA EMission Certification Plan}

Page 1 of 3

Below is the proposed emissions certification plan for the Cummins 6B Propane Engine Development, Certification \& Demonstration Project. The technically accurate name of the 6B LPG engine is the B5.9L LPG engine. For brevity and to reflect common usage, the 6B LPG name is used. Propane, or liquefied petroleum gases, is referred to as LPG. Please note that the timeframe is fluid and that there may changes based on the actual progress of certification testing and approval.

\section{PARAMETERS:}

Proposed Certification: Certification tests of the 6BLPG engine are planned per the requirements specified by the California Air Resources Board (ARB) and U.S. Environmental Protection Agency (EPA) for testing and application.

Fuel Specification: This engine is designed to use LPG that complies with the HD-5 LPG vehicular fuel specification. This specification requires a minimum of $95 \%$ LPG content within the fuel.

Catalyst: As initially proposed, certification with, and without, a catalytic converter was anticipated. However, based on previous work, it is expected that an oxidation catalyst will be required to meet the total hydrocarbons (THC) requirement for ARB / EPA requirements.

Deterioration Factor: Certification deterioration factor (DF) tests will not be required as Cummins already has an approved DF for a spark ignited lean-burn engine. This DF was based on a 1,200 hour engine test.

Emissions Targets: The 6B LPG engine certification targets are the EPA Clean Fuel Fleet Vehicle (CFFV) ultra low emission vehicle (ULEV) and proposed 2004 ARB / EPA Heavy Duty emission levels. Please refer to the following table.

The EPA CFFV program applies for fleets of 10 more vehicles which are centrally fueled, in the 22 non-attainment areas (NAA). For heavy-duty vehicles $(8,500-26,000$ gross vehicular weight [GVWR]), the requirement is $50 \%$ of the new vehicles purchased starting in 1998. A low emission vehicle (LEV) vehicle counts as 1.0 credits and a ULEV vehicle counts as 1.87 credits. Heavy-duty vehicles (over 26,000 GVWR) for these NAA fleets can generate credits though there are not required to as part of this program. Note that ARB LEV and ULEV emission standards do not apply to this engine since it is used in applications over 14,000 GVWR. 


\section{Cummins 6B Propane Engine Development, Certification \& Demonstraton Project}

\section{ARB / EPA EMISSION CERTIFICATION PLAN}

ARB / EPA Transient Heavy-Duty Engine Emissions Standard Table g/bhp-hr (g/kW-hr)

\begin{tabular}{lcccccc}
\hline & 1996 ARB / & 1998 ARB / & 1998 EPA ^ & 1998 EPA & 1998 EPA & 2004 \\
& 1998 EPA & EPA & Heavy-Duty & Heavy-Duty & Heavy-Duty & ARB / EPA \\
& Urban Bus & Heavy-Duty & CFFV LEV & CFFV LEV & CFFV ULEV & Heavy Duty \\
\hline NOx & $4.0(5.36)$ & $4.0(5.36)$ & $4.0(5.36)$ & $4.0(5.36)$ & $4.0(5.36)$ & $2.0(2.7)$ \\
THC & $1.3(1.74)$ & $1.3(1.74)$ & $1.3(1.74)$ & $1.3(1.74)$ & $1.3(1.74)$ & $0.54(0.7)^{1}$ \\
PM & $0.05(0.07)$ & $0.10(0.13)$ & $0.10(0.13)$ & $0.10(0.13)$ & $0.05(0.07)$ & $0.10(0.13)$ \\
CO & $15.5(20.8)$ & $.15 .5(20.8)$ & $15.5(20.8)$ & $14.4(19.3)$ & $7.2(9.7)$ & $15.5(20.8)$ \\
HCHO & - & - & - & 0.050 & 0.025 & - \\
\hline
\end{tabular}

${ }^{1}$ Assumed THC limit is about $90 \%$ on NMHC limit.

TIMEFRAME:

Item

Performance and Emission Optimization:

- performance engine builds

$10 / 96-3 / 97$

- test cell R\&D engine work

- vehicle drivability evaluation

- steady- state emissions testing baseline

- CVS transient emissions testing baseline

- repeat above procedure as required

- test pre-certification limited production engine builds

Plant Build/ Test of Certification Engine:

- certification limited production engine build

$4 / 97-5 / 97$

- 120 Hour Conditioning Cycle Test at Cummins ETS Facility

Engine Emissions Certification Test:

- per ARB / EPA (40 CFR 86) certification requirements; in general, this involves:

- one cold cycle ( $1 / 7$ weighted)

- one hot cycle (6/7 weighted)

- composite average result, and

- apply established DF factor 
Cummins 6B Propane Engine Development, Certification \&

Demonstraton Project

\section{ARB / EPA Emission Certification Plan}

Page 3 of 3

Submit 1997 Certification Requests to ARB / EPA:

$6 / 97$

Award of Certification from ARB/EPA:

$7 / 97$

Page 3 


\section{The ADEPT Group, Inc.}

NREL Subcontract No. AAS-7-16609-02 under Prime Contract No. DE-AC36-83CH10093

"Cummins Engine Co. B5.9 Propane Engine Development, Certification, and Demonstration Project"

Subcontractor: The ADEPT Group, Inc.; Lower-Tier Subcontractor: Cummins Engine Co.

Final Technical Report

\section{Appendix 2 - Emissions Certification Documentation}




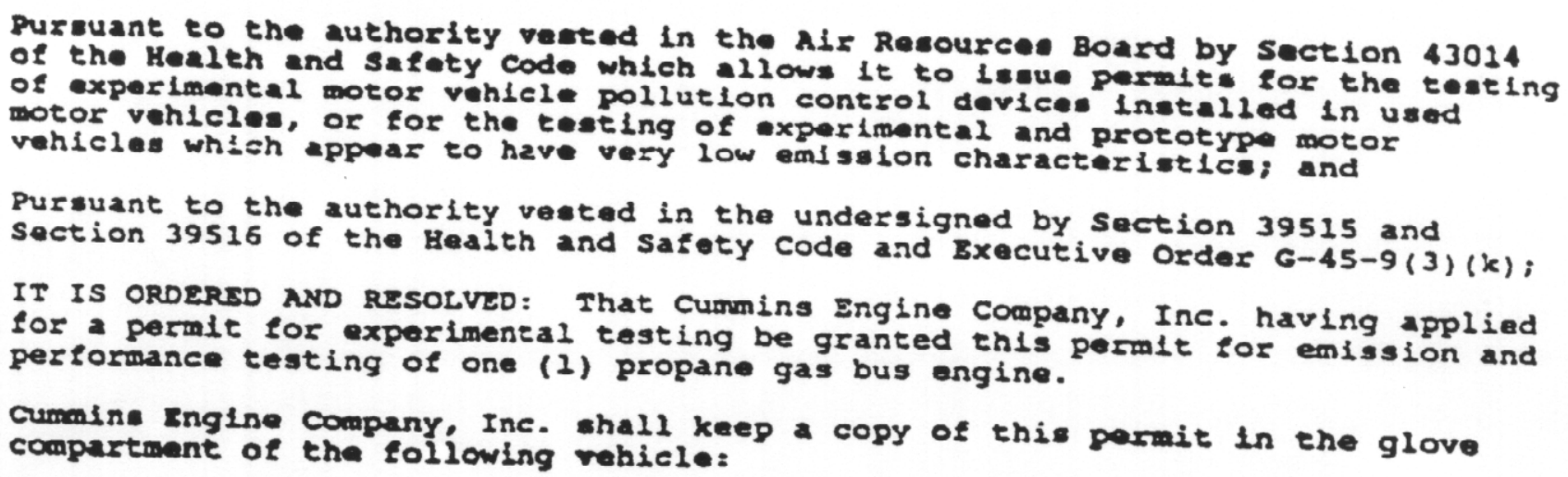

Yehtele MP

1993

\section{nakerux \\ Blueblrd o Bus IBAGBBSA8RFO61098}

\section{Engine $\mathrm{MX}$}

1998

sodel

B5.9-2306

ISN

45265227

Cumbine Engine company. Ine. ahall maintain a record of the rohicle including of the teat program and made This record hail be maintained for the duration Resources Board.

This permit is palid for one year from the date of signature. At the expiration of this permit, the vehicle must be rebulit to caj At the configuration or be shipped out of Californja. rebullt to California-certified Executed at $\mathrm{kl}$ Honte, California this qua

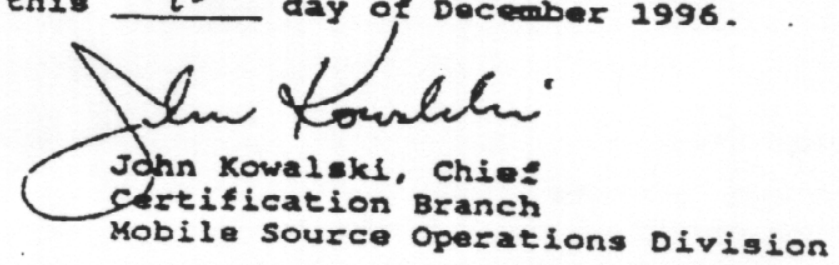


UNITED STATES SNVIRONMENTAL PROTECTION AGENCY

WASHINGTON, D.C. 20460

1997 MODEL YEAR

HEAVY-DUTY LOW EMISSION VEHICLE

CERTIFICATE OF CONFORMITY

WITH THE CLEAN AIR ACT OF 1970 ISSUED TO:

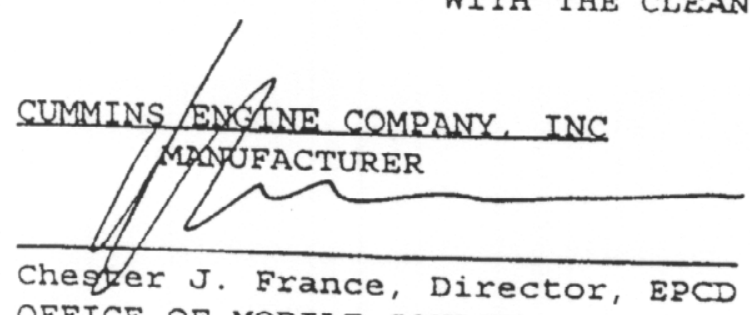

OFFICE OF MOBILE SOURCES
CUMMINS-NGE (MHDD) $-27-34$

September 5,1297

EFFECTIVE DATE

DATE ISSUED: September 8, 1997

Pursuant to Section 206 of the Clean Air Act (42 U.S.C. 7525) and 40 CFR Parts 86 ar.c which have been found to conformity is hereby issued with respect to the test engines Air pollution from New Motor Vehicles requirements of these regulations on Control of 88 ) and which represent the following motor vew Motor Engines (40 CFR Parts 86 and fully described in the application of the aehicle engines, by engine family, more

HEAVY DUTY (MEDIUM-hEAVY) NATURAL GAS FAMILY:VCE359DICAAC (493F)

This certificate of conformity covers only those new motor vehicle light heavy-duty natural gas engines which conform, in all material respects, to the design by 40 CFR parts 86 and 88 and period stated on this certificate of the produced during the model year production 86 and 88 . This certificat the effective date of the certificate.

It is a term of this certificate that the manufacturer shall consent to all inspections described in 40 CFR 86.096-7, 86.606, and 86.1006 and authoril court order may lead to revoa to comply with requirements of such a warrant or specified in $40 \mathrm{CFR}$ part 86 includin or suspension of this certificate for reasons ab initio as specified in 86.096-7. 40 CFR $86.095-30$, or render the certificate voic certificate may be revoked or suspended is also a term of this certificate that this specified in 40 CFR part 86 , including or rendered void ab initio for other reasons 86.1012 .

This certificate does not cover rehicles or engines sold, oミsered for sale, or incroduced, or delivered for introduction, into commerce in the U.S. prior to the
effective date of the certificate. 
UNITED STATZS BANTIROMMENTAL, PROTECTION AGENCY

WASHINGTON, D.C. 20460

1998 MODEL YEAR

HSAVY-DULY LOW KMISSION VEHICYS

CERTIPICATB OP CONFORMITY

WITE THE CIENN AIR ACI OF 1970 ISSUEN TO:

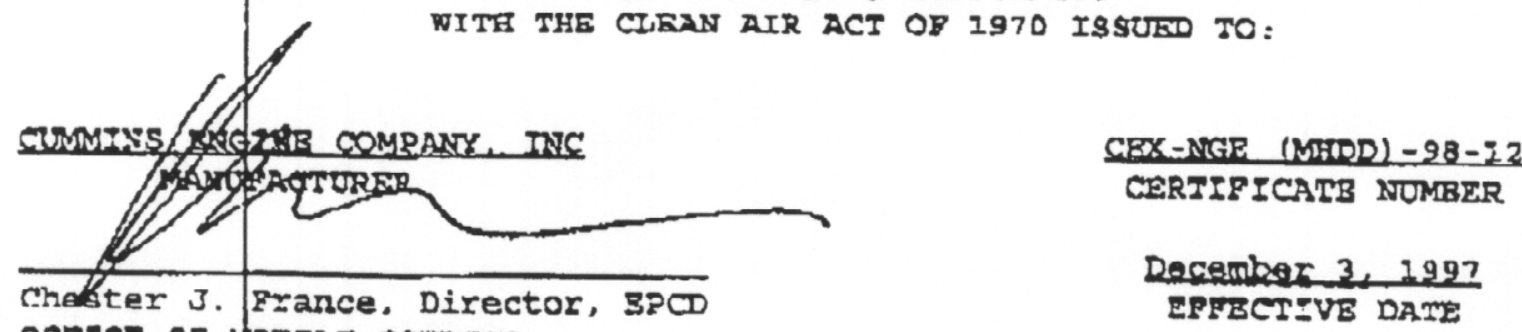

OFFICS OS NOBILE SOURCES

Darts Issurg: December 3, 1997

Pursuant to section 206 of the Clean Aiz Act (42 U.S.C. 7525) and 40 CAR Parts 86 asd 88, this ceftificate of conformity is bereby issued with respect to the test engines which repressent the following motor vehiale engines, by engine family, more eully described in tha application of tha above named manufacturer:

HBAVY DUTY (MBDIUK-MEAVY) NATURAL GAS BAMILY:WCBXI0359BAT (4938)

This certificate of conformity covers only those new motor vebicle heavy-duty natural gas engineg which conform, in all materlal reapects, to the design specifleations that applied to thope engines described in the documentation reguired by 40 CFR Partg 86 and $B \theta$ and which are produced during the model year production poriod mtated on this certifivato of the said menufzcturcr, wo defined in 40 crk parta 86 and gr. This certificats of conformity does not cover vehicles imported prior to the effective date of the cerqificate.

It is a teim of thig certificate that the manufacturer ghall congent to all 1napections deseribed in 40 CFR 86.096-7, 86.606, and 86.1006 asd authorized in a warrant or coure order. Failure to comply with requirements of such a warrant or court order may lead to revocation or suspersion of this certiflcate for reasoss opecifiod in $10 \mathrm{CBR}$ part 06 inciuding $40 \mathrm{CFR} 86.095-30$, or zender the oertifieate vold $\mathrm{ab}$ initio \&s specified in 86.096-7. It ts gla a term of this certificate that chis

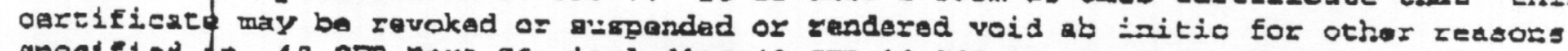
apecifled it 40 CFR pare g6, 1.xeluding 40 CFR $86.095-30,86.512,86.096-7$, and 86. 1022 .

Mis certificate does 505 cover vehicles or engines sold. offezed for sale, or introduced, or delivered for introduction, into comerco ir tis U.S. prior to tine effective dare of the certificase.

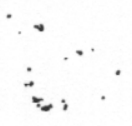


Relating to Certification of New Heavy-Duty Motor Vehicle Engines EXECUTIVE ORDER A-21-201 CLMMINS ENGINE COMPANY, INC.

Pursuant to the authority vested in the Air Resources Board by

Pursuant to the authority Health and Safety Code; and and 39516 of the Health and Safety the undersigned by Sections 39515 IT IS ORDERED AND RESOLVED: Company, Inc. 1998 model diesel the following Cummins Engine Fuel Type: Liquefied Petroleum Gas (LPG)

Engine Family WCEXH0359BAL (493F) Liters (Cubic Inches) 5.9 (359)
Exhaust Emission Control Systems and Special Features Charge Air Cooler Turbocharger Powertrain Control Module Heated oxygen Sensor Oxidation Catalytic converter

Engine models and codes are listed on attachments. The following are the certification exhaust emission standards for
this engine family in grams per brake-horsepower-hour:

$\begin{array}{ccc}\begin{array}{c}\text { Total } \\ \text { Hydrocarbons }\end{array} & \begin{array}{c}\text { Carbon } \\ \text { Monoxide }\end{array} & \begin{array}{c}\text { Nitrogen } \\ \text { Oxides }\end{array} \\ 1.3 & & \end{array}$
2.5
0.10 The following are the certification exhaust emission values for this
engine family in grams per brake-horsepower-hour:

\section{Total \\ Hydrocarbons}

0.8

\begin{abstract}
Carbon
Monoxide
\end{abstract}

1.0 \begin{tabular}{l} 
Nitrogen \\
Oxides \\
\hline
\end{tabular}

$$
2.3
$$

\section{Particulates}

0.01

BE IT FURTHER RESOIVED: That for the Iisted engine models, the manufacturer has submitted the materials to demonstrate certifi provisions with the Board's emission control demonstrate certification seq.).

(Title 13, Californission control system warranty 
BE IT FURTHER RESOLVED: That the listed engine models are certified to the optional lower-emission NOx standards pursuant to the California Code of Regulations, Title 13, Section 1956.8(a)(1) and t: incorporated "California Exhaust Emission Standards and Test

Procedures for 1985 and Subsequent Model Heavy-Duty Diesel Engines a: Vehicles", adopted April 8, 1985, as last amended June 29, 1995.

Engines certified under this Executive order must conform to all applicable California emission regulations.

The Bureau of Automotive Repair will be notified by copy of this orce and attachments.

Executed at El Monte, California this $17^{\text {th }}$ day of February 1998.

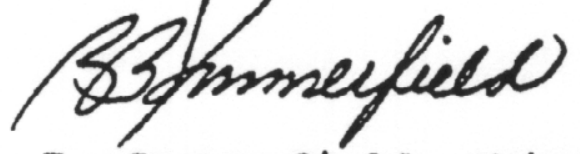

R. B. Summerfield, Chief

Mobile Source Operations Division 
NREL Subcontract No. AAS-7-16609-02 under Prime Contract No. DE-AC36-83CH10093

"Cummins Engine Co. B5.9 Propane Engine Development, Certification, and Demonstration Project"

Subcontractor: The ADEPT Group, Inc.; Lower-Tier Subcontractor: Cummins Engine Co.

Final Technical Report

\section{Appendix 3 - Cummins B5.9LPG Engine Articles}




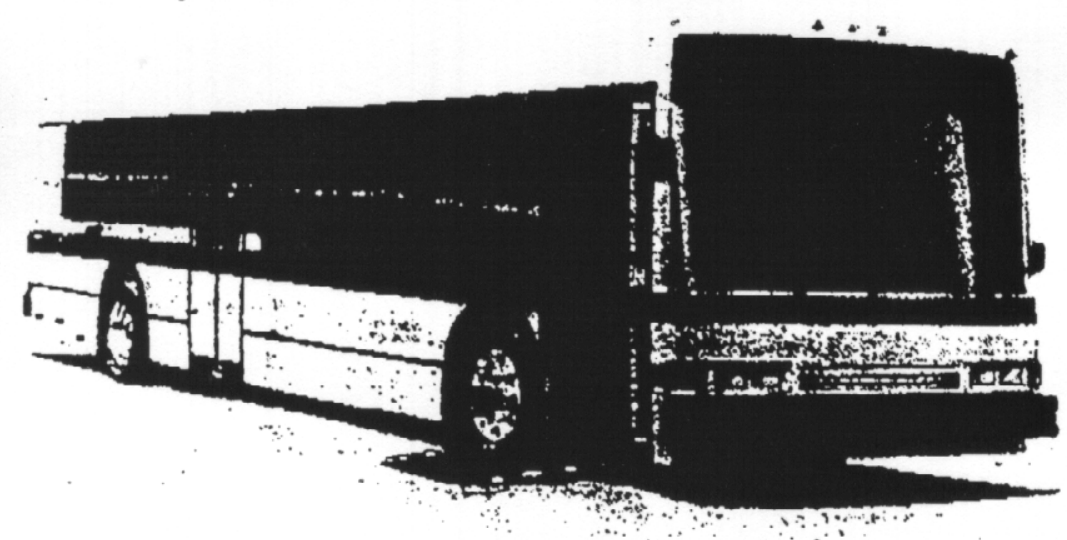

TORE THAN 2C: 20 : : Ow iloor buses from North American Bus Industries are ang added :O VIA Metropolitan Transit's fleet in San Antonio, Texas.

\section{Sam " io System To Add 283 New Vehicles by 2002}

SAY ANTON:O. TEXAS-VL Metropolitan Transit has approved the purchase of 283 new accessible low floor buses to be delivered xetween 1999 and 2002: 66 propane-powered 30-foot buses from Champion Moror Coach and 217 diesel-powered 40 -foot buses from Vorth American Bus Industries.

Of the $\$ 69.1$ million total cost for the two Jus contracts, federal grants will provide i55.3 million. The purchace, the largest bur rocurement since VIA was established in 1978, was made to help make the system more iccessible and to modernize the fleet.

Once all the new buses are delivered, 60 per:ent of VIA's fleet will be accessible - a subituntiul improvement from the current 6 pereent.

Low floor buses do not need steps at the foor because the noor is at approximately the iame height as the street curb; the buses will $x$ equipped with 3 ramp at the frant door to Hlow wheelchair access. Together, these ferures are expected to make boarding the bus nuch quicker and easier for wheclchair uscrs Ind other riders who have trouble elimbing ieps.

Doug Peck. VIA's director of vehicle muinenanec, said both ergonomics und economics sere factors in the choice of low floor vehi:les. "Customers from other transit companies ave reully likod the low floor fosture, which iso happens to be much more economical han other styles," he said.

Becsuse of the proximity to the curb level, ow floor buses eliminate the need for a lift to iccommodate some passengers. The hydraulic zmp and its controls are conveniently posiioned in the front, allowing the operator to lave a good view of the bourding process and ussist pussengers when necessary.

The bus acquisitions will complement 'LA's other efforts to build an accessible sysem for all passengers. including persons with ilsabutities.

The system is developing a new fixed route usi ridership truining program to provido peruns with disabilities and the elderly with the sills necessary to ride the bus. The program vill include nands-on instruction on how to ide the bus to work, medical incilities, or ther destinations. In addition, VIA will have pecially trained "Transit Amhassadors" vailsble to work one-on-one with people to help them overcome chstacles that might have discuuraged then from riding the bus.

While VIA currenty operatcs paratransit service to provide transporation for persons with disabilities, riding the regular bus resutes offers more flexibility and convenience for passengers. The new buses will allow the system to increase the number of accessible bus routes.

- Through these innovative programs and with these new buses, we will be able to uffer people with disabilities more options," said VLA General Mynager John Milam.

Modernizing the aging flect was another priority for VIA: 107 of the system's buses have been in operation since the late 1970s. The new buses will replace pan of VIA's ulder fleet. In fact. VIA plans to retire 329 older buses, vans, and strectcars by the ycar $2(102$. By the end of 2002, tha average uge of the fleot will be reduced from 14.86 years in 199810 7.99 years.

'The fact that we've been operating some of these vehicles for so long is ceruinly y tritute to the manufacturers and our employees in muintenance and operations," Peck suid. "But now it's time to upgrade our flect with the latest rechnology and advanced accessibility solucions."

The now vehicles also aro axpoctod to improve VLA's impact on the environment and further demonstrate the agency's commitment to the use of alternative fuels. The new 30-foot buses, equipped with the Cummins B5.9LPG low emissions vehicle propane ensine will join the 209 prupane-powered vehicles currently in V1A's fleet. In addition, the system plans to cunvert all 20 of its downtown streetcurs to propane by 1999.

While the Cummini ISC8, 3 liter diecel engine on the new 40 -joor buses is not LEV. certified. it is required to meet the 1998 Environmental Protection Agency urban transit bus emissions standards.

VIA is icheduled to receive all bo of the 30-foot buses and the first 80 of the 40 -foor huses in 1999. Eighty of the 40 -foot buses will be delivered hetwcen 2000 and 2001 , with the remaining 57 buses slated for delivery in 2002. Al that time. the agency is expected to have a total of 502 busex and 20 streetcars in operation.

\section{El Niño Doesn't Thanks to Adv

San Carlos, Caltr.-Caltrain reports that advance planning has helped to keep service on the commurer railroad on track despite this winter's RI Nino-related storms.

When talk of EI Niño escalated last suminer. Caltrain and its contract operator, Amtrak, elosely inspected the entire Caltrainowned right of way. 51 miles from San Fran clsco to San Jose.

Rail staff delermined a little prevention would go a long way in naintaining the cominuter rail service, on which 27,000 riders depend each weckday.

"Good drainage is the key to as successful railroad," said Caltrain Maintenance of Way Manager Mark Hennessy. To keep the rails

Noud- ano debris-free. additional porable purn! problam ureas. Caltruin? fencrators, to operate the event of a pou'er ou:age.

During last year's sto right of way fell across passengers. This yeur. rat trinimed trees between wood City and removed lyptus trees in Burlinge branches could damage lines required for sufe mi

Rail crews continue da trucks and surruunding $r$.
toot.

By preparing for the vented it," suid Henncsis

\section{7if Passenger \\ Transport}

IS.SN 0364-345X

The Weekly Newspaper of the Transit Industry

VOI.UME 56, NUMBER 8

ESTABLISHED 1943

Published each week, except last week in August and December, by the Amertcan Public Transtt Association, 1201 New York Ave., N.W., Washington, D.C. 20005: Tcl. (202) 898-4000: Fax (202) \$98.4095.

It is the mission of Passenger Transport to communicate news and information about public transportation and to serve as the voice of the cransil industry.

Rhonda Goldberg Managing Editor Susan Berlin Assistant Editor Cecilia M. Barber Adverrising Sales Veronika Rickurd-Amingtan Circulation

News \& Commentary: Passenger Transpor welcomes articles, announcements. commentury, and lesters to the editor from all organizations and individuals within the public transit industry.

Subscriptions: Individual subscriptions within North Americs \& U.S. postessions, \$65 per year.

Quantity discounes when billed to one ad. dress:

Subscription 4, 5 \& 6: $\$ 59$ each per year Subscription 7. 8, 9 \& 10: $\$ 52$ each per year

Subscription 11 and up: $\$ 4.5$ cach per year

First class mail for abnvc: \$38 uclelitional der year per subscription. Subscriptions outside North America: $\mathbf{5 7 7}$ per year. Ainmil service outside North America: $\$ 60$ additional per year per subscripeion.

Adverelsing: The appearance of advertisements and new product or service information in Pasteenger Trunsport does not constitute an endorsement of such produets or services by APTA.

POSTMASTER: Send address chengev to: Posienger Trunspun. 1201 New York Ave., N.W.. Washington, D.C. 20005. Periodicals Postage paid at Washington. D.C., and additional mailing offices.

\section{sी American APLA Transit A}

Pussenger Transpor 1201 New rork Ave.. $N$ D.C. 2000s: Tel. (20?) APTANet udi shtip://www:ap APTA M

APTA's mission is 16 sent its members in mad portution an offoctive i opportunity. personal n proving the quality of : nerships, communicatior advocacy.

APTA's Policy of

APTA recognizes in diversity for conference ers and is conmilted awareness of its membe issues. APTA welcome: tions on how to strengt meet thesé important dive APTA Um

Howard C. Breen

Shirley A. DeLlbero

Peter M. Cipolla

Leslle $R$. White

James S. Burbour Vice Chai John P. Bartosiewic

Christopher P. Buylan Michucl S. Connelly

Grace Crunican

Sundy Druggoo

Bemerd J. Ford Sr. Busine Cella G. Kupersmith

John K. Ltury Jr. Briun Macleod

Patricia S. Nettleship Rrsor Philip A. Pagann Comamut Ian C.. Stacey Richard A. White stana william Hi, Presiden Kurol J. Pol Chicf of Si. Vice Presidı Anthony M. Kouneski Dunicl Durt

Vivienne williams H:an.

Mary K. Ferrari the American Public Tr. 


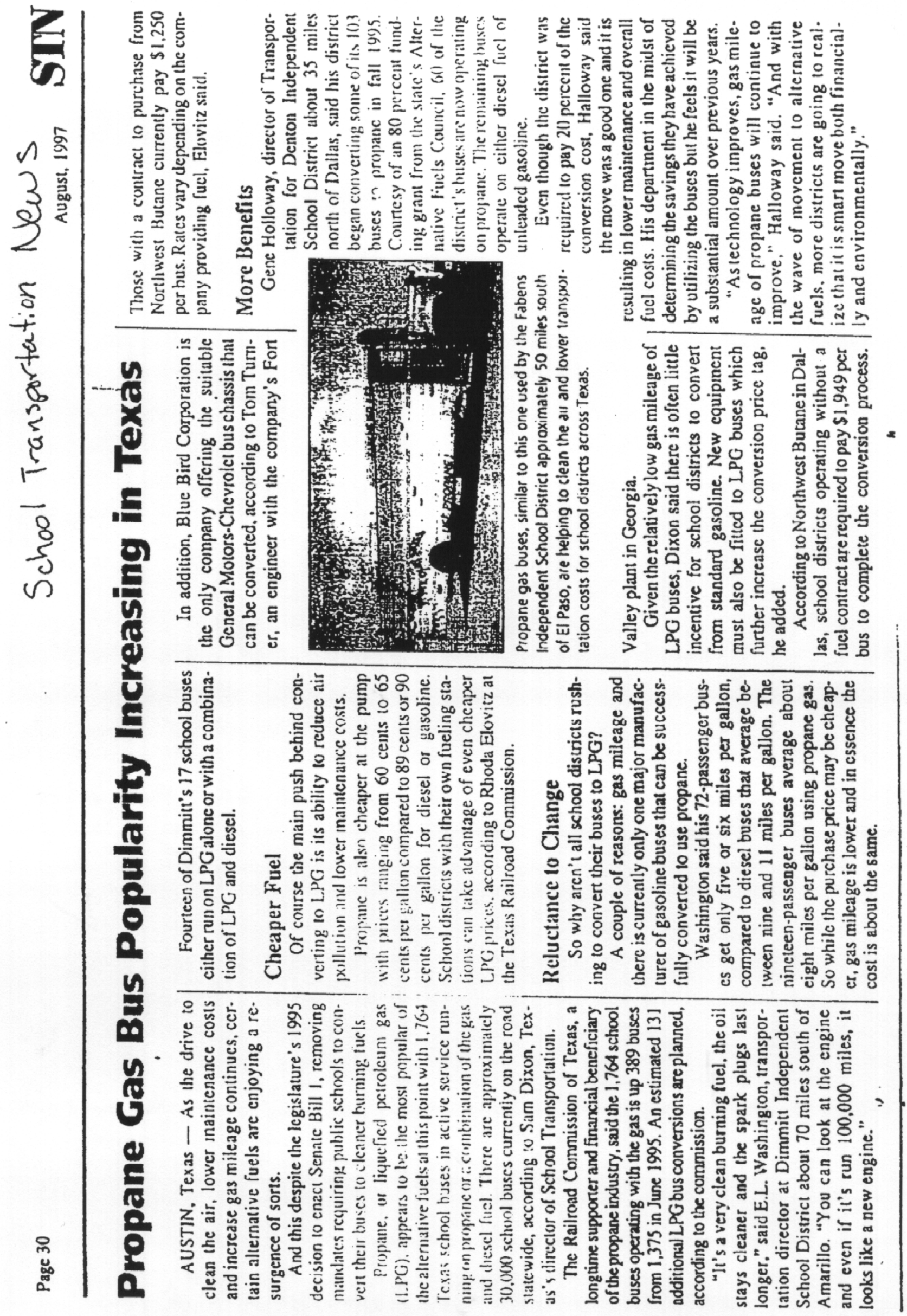




\section{New Pasadena Bus Drives Rose Parade Route Every Day}

Qome lucky bus drivers in Pasadena. Calif. get to drive a propane-fueled bus up and down much of the parade route for the "Grandaddy" of all parades, the Rose Parade. On parade every day as part of the city's transportation services, the propane-fueled Bluebird bus with a Cummins B5.9 LPG engine is one of several buses used on two routes. to provide free bus transportation

The artistically decorated buses are part of the city's etforts to help get citizens out of their cars and reduce the number of vehicles on city streets. Students in the city schools entered a contest to design the decoration for the buses. The designs that were chosen were then enlarged and placed on the buses. Most of the bus fleet currently runs on diesel. Two propane-fueled models are part of an 18-month demonstration project to determine if the alternative fuel is cost effective and works efficiently

The first bus was converted at the end of 1996. Cummins changed the diesel engine to its propane model at the manufacturer's Southern California tacility. The new fuel tanks were also installed at that time. The bus, which is :alled "the Rose Parade bus" by the sity"s transit oftice. experienced a tew minor operation problems in the beginning. Since then, according to the city aransit office. it has been operating consistently and smoothly along the 15 -mile route. The other route is 6 miles long. A second bus was to be converted at the end of Mav and be in operation shortly afterward.

\section{The "Peace Bus"}

According to Steve Moore of Mfutual Propane (Gardena, Calif.), the first bus was taken to the nearby Cummins facility to change the engine, add the two Manchester propane tanks, and make sure the vehicle was working properly. The bus has a manifolded fuel supply, an 80-gal. tank and a 35 gal. tank. For the second bus, Cummins was expected to replace the diesel engine at its facilities and Mutual would then add the tanks at its Gardena plant. The second bus is called "the
Peace bus" and is decorated with numerous symbols representing peace to different cultures

When not in operation. the buses are stored at the Laidlaw bus facility in Pasadena with the other city transit vehicles. Laidlaw, a company that offers bus and transit services to cities and other organizations, is managing the fleet for the city. Mutual installed an 1150-gal. tank and refueling equipment for the buses at a city storage site near the Laidlaw facility and close to their routes. The buses can be filled at about 12-15 gpm. Mutual said installation of the refueling site was one of the more difficult aspects of the project because the city required a lot of paperwork to be filled out as part of the permit process. Luckily, the city's transit department was helpful in handling much of the paperwork.

According to Diane Kotto of the city transit office, one of the propanefueled models will be on display at this year's Clean Cities Conference, which will be held in Long Beach. Calif., June 24-27.

\section{HEH IS THE SINGLE QUALTY SOURGE}

Celebrating 45 years of service to the propane gas industry, 1951-1996
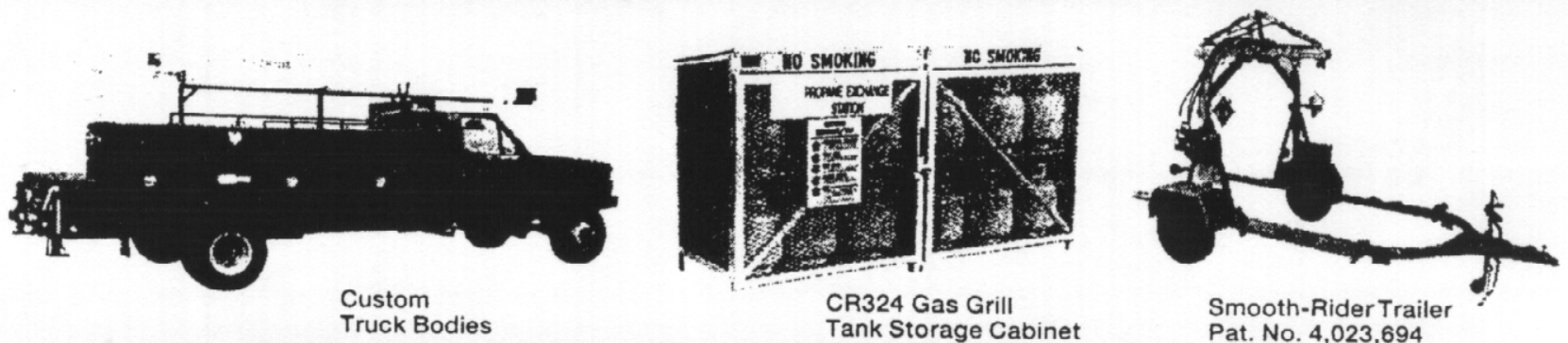

FOR ALL OF YOUR GAS HANDLING NEEDS

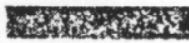

\section{Trucks, trailers, tank storage cabinets}

$\mathrm{H} \& \mathrm{H}$ can meet all of your gas handling needs. We build our gas handling equipment knowing you need and expect quality and performance. $\mathrm{H} \& \mathrm{H}$ builds it all in. You'll reduce labor, increase safety, and save time and money.

Truck Bodies - We design our truck bodies with your field service work in mind. Transport, service or deliver cylinders and other aw/kward loads anywhere. Large or small, custom or standard. steel or aluminum. H\&H offers a large choice of options, including in-bed lift platforms, electric or hydraulic cranes, grated or diamond plated flooring, and more.

Trailers - Our Smooth-Rider ${ }^{\top M}$ bulk tank trailers are built to make moving tanks a breeze. They cushion the load with rubber torsion axles. One person can operate these trailers with your choice of octions: hydraulic hoist, dual-cable top. mount or side mount electric winch, or hand winch.

Tank storage cabinets - Our rugged Cylinder-Stor cabinets are built for secure outside storage of cylinders, giving you better inventory control and bigger profits. Single- and double-section modeis are furnished with keyed padlocks, tamper-proof padlock hasps, reinforced back panels, and bolt-down features for complete security and safety.

Talk - Call H\&H today: 800-551-9341.

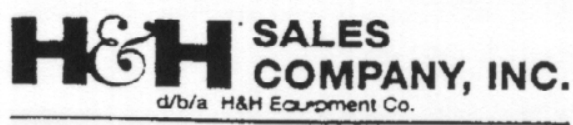

CUSTOM TRUCK BODIES AND MANUFACTURING

16339 Lima Rc. PO Box 686 -

phone: $217-537-3177.800-5 \Sigma 1.3341$. FAX 219-637-6880

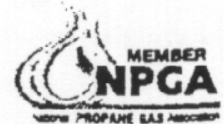


The $\$ 5$ million Sourhern California Ozone Study (SCOS97) conducted during the summer of 1997 will help wich chose planning efforts. AQMD was a major participant in the efforr. which used laser lighe beams, aircraft and balloorns to gather data. The study provided a wealch of information to determine how smog rravels from one region to another and will help

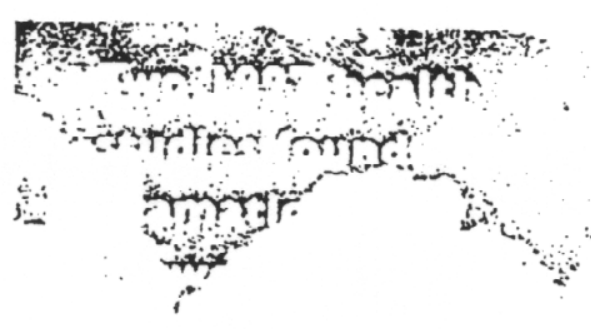

Fuel cells combine hydrogen and oxyger to produce electricity, emitring only water vapor.

AQNirds Technoiogy Advancement Office (TAO) has been a major proponent and contributor in the development of fuel cells since the lace $1980 \mathrm{~s}$. In 1997 , the Governing Board approved 42 centracts for fucl cells and orher clean fuel predict when the region will achieve clean air.

$$
35
$$

\section{Health News}

Two healch studies sponsored by AQMD and reporred in 1997 found dramatic links between ozone and particulate pollution in Sourhern California and hospitalizations, emergency room visits and premature deachs. The studies are significant because they paired detailed daily air quality data in the Southland with local hospical records.

One study surveyed hospital records of more than 1.6 million Kaiser Permanente parients. The results suggest that each 10 microgram increase in the coarse fraction of PM $_{10}$ is associated with a $7 \%$ increase in hospital admissions for chronic respiratory disease -- twice the rate reported in other areas of the country.

A second scudy found that a 10 microgram increase in $\mathrm{PM}_{10}$ in the Coschella Valley was associaced with a $2.5 \%$ increase in emergency room visits for pneumonia and a $1 \%$ increase in deachs.

\section{Clean Fuel Technologies}

AQMD launched its Technology

Advancement Office in 1988 to promote the development of advanced clean fuel rechnologies.

Clean fuel rechnolugies trok a gianr leap forward in 1997 wich majot auromakers pledging nearly $\$ 1$ billion toward research and development of fuel cell-powered clectric automabiles.

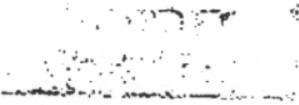

cechnologies totaing $\$ 5$ million. Cost-sharing from orher agencies and private fiems will boost the value of the projects to $\$ 17.1$ million. include:

Milestones of TAO-sponsored projects in 19.97

- Complerion of chree fuel cell-potvered urility vehicles -- the only ones in daily use in the world -- in the City of Palm Deserc;

- Building of an affordable electric car prototype with detailed plans on how ic could be mass-produced in California;

- Completion of a one-year scudy demonstrating that professional "wer cleaning" of garments with soap and water is a viable substitute for dry cleaning, which uses rhe roxic chemical perchlorocthylene;

- Developmenc of a new locomotive engine design using liquid narural gas fuel that cuts nitrogen oxide emissions by $75 \%$ and virtually eliminates soot. The technology will be demonstrated in the near future in a Mecrolink train; and

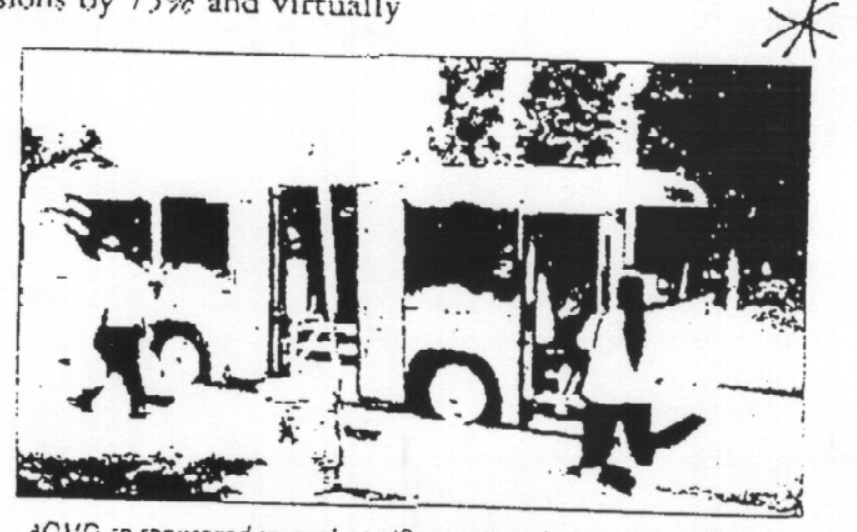

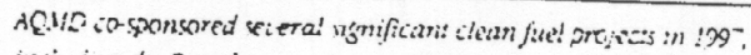

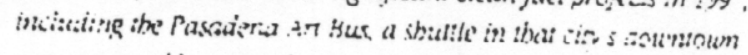

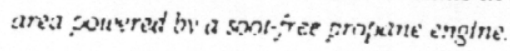




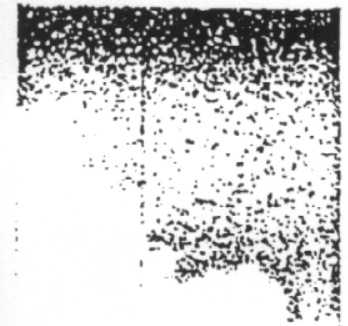

\begin{abstract}
- Praduction
of rhe first

medium-di-y

proparte tigne

cerrified to meer

low emissioni

stanciards by the

California Air
\end{abstract}

Resinurces Board.

\section{MSRC Programs}

In 1997 , the Moditc Source Air Pollution

Reduction Review Commicree (MSRC)

awarded \$ : million in contracts on co-fund

zero- and uitra-low-cmission vehicles,

transportation management and local

government air qualicy programs. MSKC is an independent encicy whose projecrs are approved by $A Q M D$ 's Governing Board. Since 1995, MSRC's "Quick Charge" program has been instrumental in purting more than 300 electric véhicles on Sourhland streets and installing more than 400 electric vehicle charging stacions.

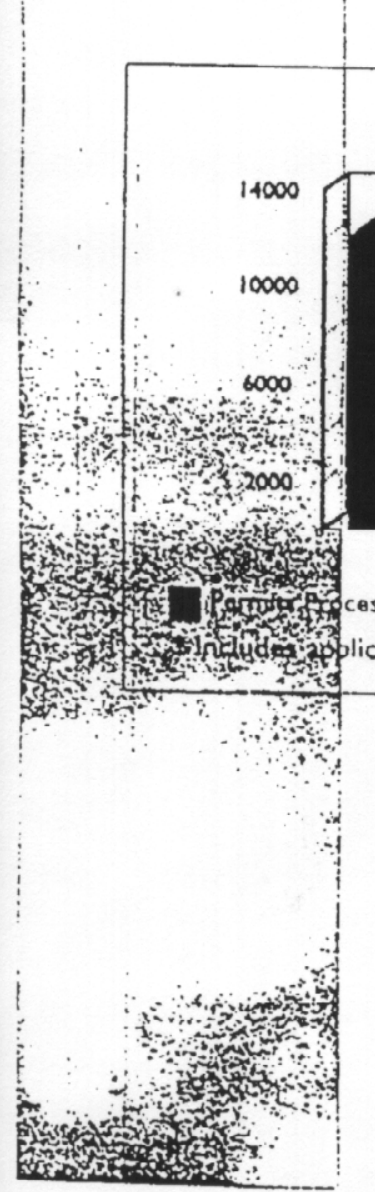

\section{Permitting Activity}

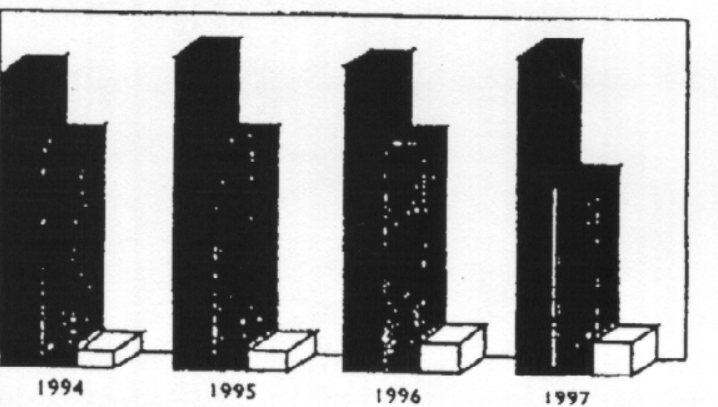

Permics to Operate Permiles co Consuruct ications canceled. expired and denied

\section{Permit Streamlining}

AQMD staff took several steps in 1997 in streamline permit processing, including:

- Simplifying permir applications, resuleing in $50 \%$ fex filing etrors;

- Streamlining applicarions for major sources in Title $V$, the new federal operating permit program: and
Maintaining derailed permit applicarion instructions and downloadable forms on AQMD's Wessite. Businesses can cren submis applications for some communly ușed equipment over the Incernet.

But the region's rebounding econony, more complex federal permitring requirements and a smaller AQMD workforce caused a small but worrisome increase in the permit backlog by year's end. AQMD plans to reallocace staff ro permic processing and pursue additional permit streamlining in 1998 to reduce that backlog.

\section{Business Assistance}

During 1997, AQMD's Office of Public Affairs Business Assistance Group engaged in several activities to help firms comply with air quality regulations, including:

- Assisting officials at an Encenmann's Bakery facility in Moncebello, who were contemplating a cost-saving move to Cencral California, to instead modernize their
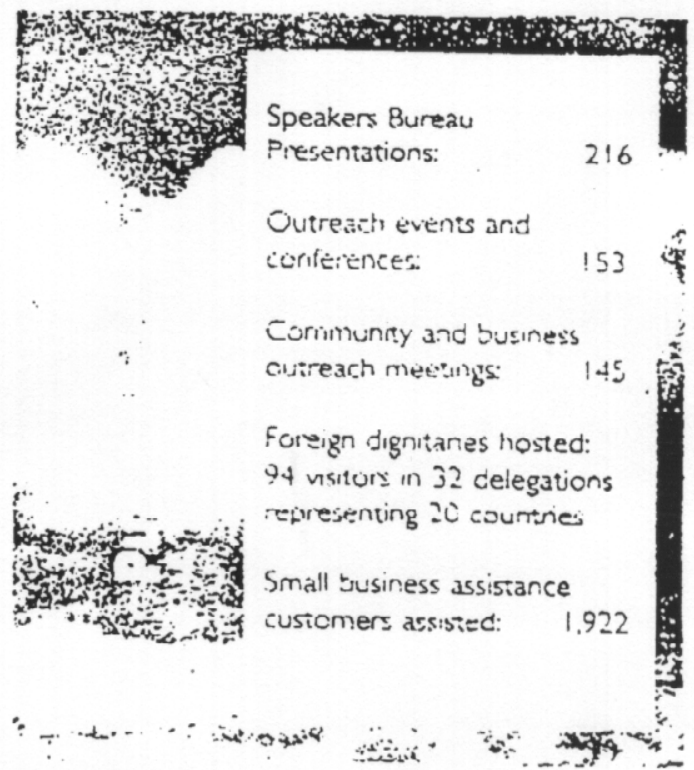


\section{REPORT DOCUMENTATION PAGE}

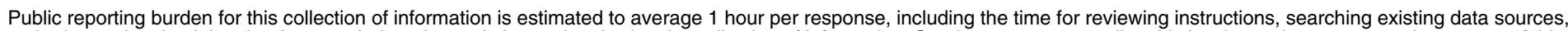

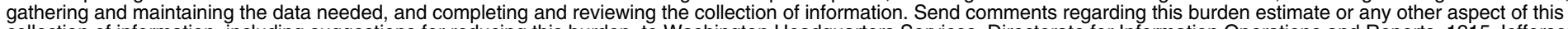

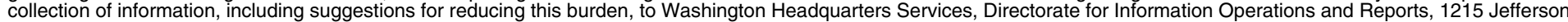

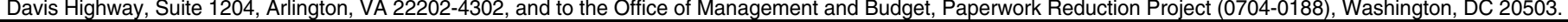

\begin{tabular}{|l|l|l|}
\hline 1. AGENCY USE ONLY (Leave blank) & $\begin{array}{l}\text { 2. REPORT DATE } \\
\text { November } 1998\end{array}$ & $\begin{array}{l}\text { 3. REPORT TYPE AND DATES COVERED } \\
\text { Subcontract report }\end{array}$ \\
\hline
\end{tabular}

4. TITLE AND SUBTITLE

Cummins Engine Company B5.9 Propane Engine Development, Certification, and Demonstration Project: February 1997June 1998

6. AUTHOR(S)

The ADEPT Group

7. PERFORMING ORGANIZATION NAME(S) AND ADDRESS(ES)

8. PERFORMING ORGANIZATION

The ADEPT Group REPORT NUMBER

1575 Westwood Blvd., Suite 200

Los Angeles, CA 90024

9. SPONSORING/MONITORING AGENCY NAME(S) AND ADDRESS(ES)

National Renewable Energy Laboratory

1617 Cole Blvd.

5. FUNDING NUMBERS

(C) AAS-7-16609-02

(TA) FU913410

Golden, CO 80401

10. SPONSORING/MONITORING AGENCY REPORT NUMBER

NREL/SR-540-25114

\section{SUPPLEMENTARY NOTES}

12a. DISTRIBUTION/AVAILABILITY STATEMENT

12b. DISTRIBUTION CODE

National Technical Information Service

U.S. Department of Commerce

5285 Port Royal Road

Springfield, VA 22161

13. ABSTRACT (Maximum 200 words) The objective of this project was to successfuly develop and certify an LPG-dedicated medium-duty original equipment manufacturer (OEM) engine that could be put into production. The engine was launched into production in 1994, and more than $800 \mathrm{~B} 5.9 \mathrm{G}$ engines are now in service in the United States and abroad. This engine is now offered by more than 30 bus and truck OEMs.

14. SUBJECT TERMS

Alternative transportation fuels, liquefied petroleum gas, propane, engine development

15. NUMBER OF PAGES

44

16. PRICE CODE

18. SECURITY CLASSIFICATION OF THIS PAGE
19. SECURITY CLASSIFICATION OF ABSTRACT
20. LIMITATION OF ABSTRACT 